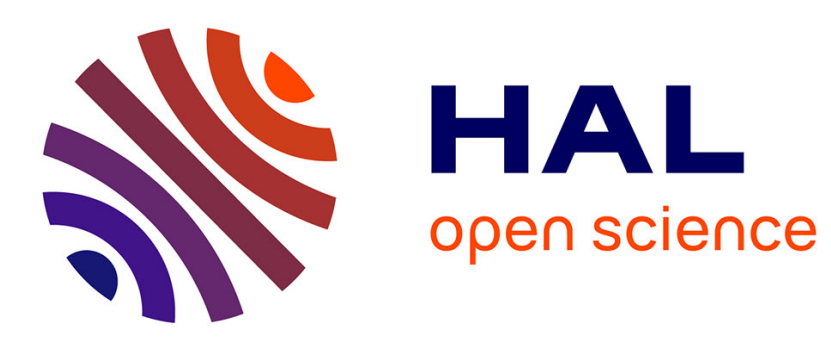

\title{
The December 22, 2018 Anak Krakatau, Indonesia, Landslide and Tsunami: Preliminary Modeling Results
} Alexandre Paris, Philippe Heinrich, Raphael Paris, Stéphane Abadie

\section{To cite this version:}

Alexandre Paris, Philippe Heinrich, Raphael Paris, Stéphane Abadie. The December 22, 2018 Anak Krakatau, Indonesia, Landslide and Tsunami: Preliminary Modeling Results. Pure and Applied Geophysics, 2020, 177, pp.571-590. 10.1007/s00024-019-02394-y · hal-02428150

\section{HAL Id: hal-02428150 https://hal-univ-pau.archives-ouvertes.fr/hal-02428150}

Submitted on 6 Jan 2020

HAL is a multi-disciplinary open access archive for the deposit and dissemination of scientific research documents, whether they are published or not. The documents may come from teaching and research institutions in France or abroad, or from public or private research centers.
L'archive ouverte pluridisciplinaire HAL, est destinée au dépôt et à la diffusion de documents scientifiques de niveau recherche, publiés ou non, émanant des établissements d'enseignement et de recherche français ou étrangers, des laboratoires publics ou privés. 


\title{
The December 22, 2018 Anak Krakatau, Indonesia, landslide and tsunami: preliminary modeling results
}

\author{
Alexandre Paris · Philippe Heinrich • \\ Raphaël Paris · Stéphane Abadie
}

Received: date / Accepted: date

\begin{abstract}
On the evening of December 22, 2018, the coasts of the Sunda Strait, Indonesia, were hit by a tsunami generated by the collapse of a part of the Anak Krakatau volcano. Hundreds of people were killed, thousands were injured and displaced. This paper presents a preliminary modeling of the volcano flank collapse and the tsunami generated based on the results of a $2 \mathrm{D}$ depth-averaged coupled model involving a granular rheology and a Coulomb friction for the slide description and dispersive effects for the water flow part. With a reconstructed total volume (subaerial and submarine) of the landslide of 150 million $\mathrm{m}^{3}$ inferred from pre and post-collapse satellite and aerial images, the comparison of the simulated water waves with the observations (tide gauges located all around the strait, photographs and field surveys) is satisfactory. Due to the lack of information for the submarine part of the landslide,

A. Paris and P. Heinrich

CEA, DAM, DIF, 91297 Arpajon Cedex, France

E-mail: alexandre.paris@cea.fr

R. Paris

Université Clermont Auvergne, CNRS, IRD, OPGC, Laboratoire Magmas et Volcans, F63000 Clermont-Ferrand, France

S. Abadie and A. Paris

Université de Pau et des Pays de l'Adour, E2S UPPA, SIAME, Anglet, France
\end{abstract}


the reconstructed submarine slope is assumed to be approximately constant. A significant time delay on the results and particularly in the Bandar Lampung Bay could be attributed to imprecisions of bathymetric data. The sensitivity to the basal friction and to dispersive effects is analyzed through numerical tests. Results show that the influence of the basal friction angle on the simulated wave heights decreases with distance and that a value of $2^{\circ}$ gives consistent results with the observations. The dispersive effects are assessed by comparing water waves simulated by a shallow water model and a Boussinesq model. Simulations with frequency dispersion produce longer wave periods and smaller wave amplitudes in the Sunda Strait and particularly in deep waters.

Keywords Tsunami $\cdot$ Landslide $\cdot$ Anak Krakatau $\cdot$ Simulation

\section{Introduction}

Landslide tsunamis are not very well known to the general public, although they are quite common and devastating. This phenomenon can happen wherever weakened volumes of rocks or sediments lie, i.e in deltas, coastal cliffs, rivers, fjords and lakes (Masson et al. 2006). As the velocity of the terrain deformation due to a landslide can reach very high values (up to $100 \mathrm{~m} \cdot \mathrm{s}^{-1}$ according to Satake et al. (2002)), the tsunami energy may be initially of the same order as that generated by a major earthquake Okal and Synolakis, 2003), but the generated amplitudes generally decrease quickly and the tsunami effects are local.

One of the largest landslide tsunamis may probably be the Storegga slide, off Norway, with its volume between 2400 and $3200 \mathrm{~km}^{3}, 8200$ years ago (Haflidason et al., 2004, Bondevik et al., 2005). Another famous case is the 1958 Lituya Bay landslide-generated mega-tsunami (Miller, 1960). After a 8.3magnitude earthquake, a volume of 30.6 million $\mathrm{m}^{3}$ collapsed in Gilbert Inlet, generating a tsunami which run-up height reached $524 \mathrm{~m}$ on the opposite side (Fritz et al. 2009). 
Until now, one of the deadliest recent landslide tsunamis is the Papua New Guinea one, 1998, during which over 2100 people died after a $4 \mathrm{~km}^{3}$ landslide collapsed at a depth of $550 \mathrm{~m}$, generating a tsunami with run-up heights up to $15 \mathrm{~m}$ (Heinrich et al. 2001a; Synolakis et al., 2002). More recently, the 2014 Tangjiaxi, China (0.16 million $\mathrm{m}^{3}, 3$ deaths, 9 people missing and 11 injured (Huang et al. 2017)), the 2017 Karrat Fjord, Greenland (50 million $\mathrm{m}^{3}, 4$ people killed (Paris et al., 2019)) events and now the 2018 Anak Krakatau, Indonesia collapse remind us of the threat landslide tsunamis represent, even if their volume appear relatively small compared to historical events such as Ritter Island in 1888 (5 km³ (Cooke, 1981, Johnson, 1987)) and OshimaOshima in 1741 (2.4 km³ (Satake and Kato, 2001).

A possible way to better understand a physical phenomenon is to use numerical modeling. A review of landslide-generated tsunami models can be found in Heidarzadeh et al. (2014) and Yavari-Ramshe and Ataie-Ashtiani (2016). Two approaches are used to simulate landslide-generated tsunamis: simulate the tsunami propagation considering the bottom deformation due to the landslide as a boundary condition for the water surface elevation or simulate both the landslide and the tsunami in a single model. In the first category, the landslide movement is reproduced as a bathymetry deformation in time (see Harbitz (1992), Grilli and Watts (2005) or Tappin et al. (2008)). In the second category, the landslide is modeled together with the free surface using a rheology law. Among them we can find Newtonian fluid approaches as in the numerical experiments of Fine et al. (2003), or in the modeling of the 1979 Nice events Assier-Rzadkiewicz et al. 2000), or in the Franz et al.s (2015) study of the 2006 Nicolet, Québec, Canada, landslide. Non-Newtonian models such as the Bingham model of Skvortsov and Bornhold (2007) or the BING model (e.g. the modeling of the 1888 Brattora, Norway, landslide tsunami (L'Heureux et al. 2011) or the 2014 submarine landslide at Statland, Norway Glimsdal et al. 2016)) can also be used. Finally, landslides rheologies can be modeled as granular flows, as in the study of Reunion Island landslide-tsunamis by 
Kelfoun et al. (2010) or the Güimar debris avalanche simulation of Giachetti et al. (2011).

Landslides are mostly simulated using 2D depth-averaged (2DH) models, although more complex and time-consuming 3D computations may be envisaged (Løvholt et al., 2008; Abadie et al., 2012, Horrillo et al., 2013). Nevertheless, they are generally spatially restricted to the landslide and wave generation area. Tsunami propagation can be realized in $2 \mathrm{DH}$ using shallow water equations (Jiang and LeBlond, 1992 , Harbitz et al., 1993) or Boussinesq equations (Tappin et al., 2014, Harbitz et al., 2014, Grilli et al., 2015). Here, we use the 2D depth-integrated model AVALANCHE (Heinrich and Piatanesi, 2000, Hébert et al. 2002, Le Friant et al., 2003) that has been successfully employed to simulate subaerial or submarine landslides (Rodriguez et al. 2013 , Poupardin et al., 2017; Paris et al., 2019), considering the landslide as a granular flow following a Coulomb frictional law and using shallow water or Boussinesq equations.

On December 22, 2018 at 13:50 UTC (20:50 local time) the southwestern flank of Anak Krakatau volcano (Sunda Strait, Indonesia) collapsed to the sea and generated a tsunami that devastated the coasts of Java and Sumatra, killing more than 430 people and damaging thousands of houses and boats, as reported by BNPB (Badan Nasional Penanggulangan Bencand ${ }^{1}$ ). Human casualties and material losses were recorded all around the Sunda Strait, on the islands of Java and Sumatra, with run-up heights reaching up to $14 \mathrm{~m}$ (TDMRC, 2019). A summary of the available observations data is provided in Section 3. This Anak Krakatau event was recently studied by Grilli et al. (2019), using the 3D model NHWAVE (Ma et al., 2012, 2015; Kirby et al. 2016) for the landslide simulation and the tsunami generation, then the $2 \mathrm{D}$ model FUNWAVE-TVD (Shi et al. 2012) for the tsunami propagation. It was also simulated by Heidarzadeh et al. (2020) using the COMCOT model (Cornell Multi-grid Coupled Tsunami Model (Liu et al., 1998; Wang and Liu,

1 https://bnpb.go.id/volume-tubuh-gunung-anak-krakatau-berkurang-jumlah-korbantsunami-bertambah, last accessed 10 september 2019 
2006)) and an initial sea surface elevation as the landslide source. We present a comparison between water heights of the two latter mentioned studies and our simulation.

In this paper, the landslide-generated water waves are calculated by AVALANCHE and compared with available tsunami observations around Sunda Strait (tide gauge records, wave heights, and flow depths, inundation heights and run-up heights reported from three field surveys). The influence of the rheology on water wave heights is discussed using different basal friction angle values and finally the dispersive effects are assessed through numerical tests comparing a shallow water to a Boussinesq model.

\section{Geological setting}

The Krakatau volcanic complex is a group of islands that lies in the middle of the Sunda Strait, between Java and Sumatra. The tectonic setting of the strait is characterized by an extensional regime that formed different grabens at the southeastern end of the Sumatra fault zone Harjono et al. 1991: Susilohadi et al. 2009). With a water depth not exceeding $200 \mathrm{~m}$, the eastern part of the strait is relatively shallow, compared with the $1000 \mathrm{~m}$ deep Semangko graben to the west (see Figure 2 in Susilohadi et al. (2009)).

Krakatau is the only active volcano of a south-southwest to north-northeast volcanic line that extends across the strait from Ujung Kulon in western Java to Rajabasa in eastern Sumatra (Nishimura et al. 1986). The 1883 calderaforming eruption completely reshaped the morphology of the Krakatau volcanic complex (e.g. Simkin and Fiske (1983)), and the present-day active edifice Anak Krakatau ('child of Krakatau' in Indonesian) was built on the steep northeast wall of the submarine caldera that was formed during the 1883 eruption (Deplus et al. 1995). The $5 \times 4 \mathrm{~km}^{2}$ large rectangular caldera is characterized by a flat bottom of 200-240 m deep. The location of Anak Krakatau on the northeast rim of this steep-sided submarine basin led several authors to question its stability (Camus et al., 1987, Deplus et al., 1995, Giachetti et al., 
2012). During this 1883 eruption, a tsunami was generated, reaching 15 up to $40 \mathrm{~m}$ run-up heights in the Sunda Strait (Nomanbhoy and Satake, 1995, Choi et al., 2003) and killing more than 35000 people (Sigurdsson et al., 1991).

Anak Krakatau first emerged from the sea in January 1928 (Stehn, 1929). From 1928 to 1959 phreatomagmatic activity progressively formed a $1.7 \mathrm{~km}$ large, $150 \mathrm{~m}$ high tuff-ring (Sudradjat, 1982). In 1960, eruptive activity shifted to a Strombolian style, thus building a new cone on the SW flank of the initial tuff-ring. During the last 60 years, recurrent lava flows and pyroclastic fall deposits contributed to the growth of Anak Krakatau Island, and the cone was $350 \mathrm{~m}$ high before its collapse in December 2018. Photographs captured from the coast of Java ${ }^{2}$ confirmed that the cone had grew by almost $100 \mathrm{~m}$ between July 2016 and December 2018. There are many coastal resorts, harbors and cities within a radius of $60 \mathrm{~km}$ around the volcano (e.g. Kalianda in Sumatra, Anjer, Labuhan and Sumur in Java (Figure 1)).

\section{Anatomy of the event}

Before any satellite revealed the effects of the on-going volcanic eruption and collapse, photographs captured by Øystein Lund Andersen in Anjer-Kidu (western coast of Java, $50 \mathrm{~km}$ east of Krakatau volcano) show a strong strombolian activity (Figure 2a), followed by a phase of ash emission that blurred the entire volcano (Figure $2 p$ ). The collapse was recorded on a seismic signal at 20:55 local time, i.e. 13:55 UTC (Walter et al., 2019). The flank collapse which removed 93.8 million $\mathrm{m}^{3}$ of subaerial volcanic rocks from the western side of the volcano (Gouhier and Paris, 2019) followed a period of 6 months of volcanic activity and rapid growth of the volcanic cone (Gouhier and Paris, 2019; Walter et al., 2019).

Local effects of the tsunami generated by the flank collapse are visible on Rakata Island (Figures 3a, b and c) and Sertung Island (Figure 3d). Taking

2 https://www.oysteinlundandersen.com/krakatau-volcano-witnessing-the-eruptiontsunami-22december2018/ 
into account the trimline, the run-up height is estimated to 25 up to $30 \mathrm{~m}$ on Rakata and Sertung islands, located respectively $4 \mathrm{~km}$ south and $3 \mathrm{~km}$ north-northwest of Anak Krakatau Island.

About 33 min after the collapse, the tsunami was recorded at Marina Jambu, Banten, east of the volcano on Java Island (Figure 11), with a first water wave height of $60 \mathrm{~cm}$ and 6 min later a $20 \mathrm{~cm}$ high wave was recorded at Ciwandan, north of Marina Jambu (Figure 4). At the same time, on Sumatra Island, a tide gauge located at Kota Agung, NW of the Anak Krakatau, recorded a wave height of $35 \mathrm{~cm}$. Finally, $58 \mathrm{~min}$ after the collapse, the tsunami was recorded in the Bandar Lampung Bay at Panjang, north of the volcano, with a wave height of $37 \mathrm{~cm}$. Note that for the two locations of Marina Jambu and Ciwandan, on Java Island, the first wave is not the highest one. In both cases, the second wave height is twice or more the first one and reached 140 $\mathrm{cm}$ at Marina Jambu, and $40 \mathrm{~cm}$ at Ciwandan.

Thanks to the work of the Copernicus program ${ }^{3}$, preliminary summary maps about the consequences of the tsunami were made available. These maps give an idea about inundation distances and damages on houses. On Java Island, the most affected areas are Labuhan, with up to $300 \mathrm{~m}$ of inundation distance and Tanjung Lesung (see Figure 1 for locations), where the water entered up to $430 \mathrm{~m}$ inland. South of Tanjung Lesung, a Youtube vided 4 shows a water wave, that can be estimated between 1 and $2 \mathrm{~m}$ high, destroying a concert stage. Elsewhere, the inundation distances reached approximately 35 $\mathrm{m}$ north of Anjer-Kidu, $50 \mathrm{~m}$ at Teluk Lada, $170 \mathrm{~m}$ at Carita, $200 \mathrm{~m}$ south of Anjer-Kidu, and $250 \mathrm{~m}$ in Sumur. On Sumatra Island, the water penetrated the land up to $150 \mathrm{~m}$ at Lampung, $250 \mathrm{~m}$ at Kalianda and $280 \mathrm{~m}$ at Taman Agung. Locations, inundation distances and recorded water heights are summarized in Figure 1 and Table 1.

Finally, the field surveys conducted by the KKP (Kementerian Kelautan dan Perikanan, Ministry of Marine Affairs and Fisheries) south of Tanjung

3 https://emergency.copernicus.eu/mapping/list-of-components/EMSR335

4 https://www.youtube.com/watch?v=2ERXCR86GU4 
Lesung and between Labuhan and Anjer-Kidu (Muhari et al., 2019), the BMKG (Badan Meteorologi, Klimatologi, dan Geofisika) at Tanjung Lesung and Carita, and the Tsunami and Disaster Mitigation Research Center of Syiah Kuala University confirmed that the areas of Tanjung Lesung, Labuhan, Carita and Anjer-Kidu on Java Island and Kalianda on Sumatra Island were among the most impacted, with destroyed brick walls and boulder(s) displaced (TDMRC, 2019). These different field surveys confirmed that the waves penetrated up to $300 \mathrm{~m}$ inland at Tanjung Lesung (run-up height of $5 \mathrm{~m}$ asl), $170 \mathrm{~m}$ at Carita (run-up height of $6.2 \mathrm{~m}$ asl) and $330 \mathrm{~m}$ at Sakarame, north Carita (run-up height of $4.6 \mathrm{~m}$ asl). A local run-up height of $13.5 \mathrm{~m}$ asl for an inundation distance of $125 \mathrm{~m}$ was measured in a location between Tanjung Lesung and Sumur. Another remarkable run-up height of $12.5 \mathrm{~m}$ was measured at Cipenyu Beach by Takabatake et al. (2019). The locations of the places studied by these field surveys are listed in Tables 2 and 3 .

\section{Methods}

\subsection{Landslide model}

In the code AVALANCHE (Heinrich et al. 2001b, Paris et al., 2019) the flank collapse is modeled using the one-phase grain-flow model of Savage and Hutter (1989) and a Coulomb basal friction. The equations of conservation of mass and momentum are solved in a $\left(x^{\prime}, y^{\prime}\right)$ coordinate system linked to the topography (Figure 5):

$$
\frac{\partial h_{s}}{\partial t}+\frac{\partial}{\partial x^{\prime}}\left(h_{s} u_{s}\right)+\frac{\partial}{\partial y^{\prime}}\left(h_{s} v_{s}\right)=0
$$

$\frac{\partial}{\partial t}\left(h_{s} u_{s}\right)+\frac{\partial}{\partial x^{\prime}}\left(h_{s} u_{s}^{2}\right)+\frac{\partial}{\partial y^{\prime}}\left(h_{s} u_{s} v_{s}\right)=-\frac{1}{2} \kappa \frac{\partial}{\partial x^{\prime}}\left(g h_{s}^{2} \cos \theta\right)+\kappa g h_{s} \sin \theta_{x}+F_{x^{\prime}} ;$

$\frac{\partial}{\partial t}\left(h_{s} v_{s}\right)+\frac{\partial}{\partial x^{\prime}}\left(h_{s} v_{s} u_{s}\right)+\frac{\partial}{\partial y^{\prime}}\left(h_{s} v_{s}^{2}\right)=-\frac{1}{2} \kappa \frac{\partial}{\partial y^{\prime}}\left(g h_{s}^{2} \cos \theta\right)+\kappa g h_{s} \sin \theta_{y}+F_{y^{\prime}}$ 
where $h_{s}$ is the slide's thickness in a direction perpendicular to the slope, $\mathbf{u}=\left(u_{s}, v_{s}\right)$ the depth-averaged velocity vector parallel to the slope, $\kappa=$ $1-\rho_{w} / \rho_{s}$ where $\rho_{w}$ and $\rho_{s}$ are the water and rock densities with a ratio $\rho_{s} / \rho_{w}=1.5$ (for the subaerial part of the slide, $\kappa$ is equal to 1 ), $\theta(x, y)$ the local steepest slope angle, $\theta_{x}$ and $\theta_{y}$ the slope angles along the $x$ and $y$ axes respectively, and $\mathbf{F}=-\kappa g h_{s} \cos (\theta) \tan (\phi) \mathbf{u} /\|\mathbf{u}\|$ the friction forces, where $\phi$ is the friction angle of the sliding materials. Curvature terms representing the effects of coordinate transformations (Savage and Hutter, 1991) are considered as second-order terms in this paper. In this set of equations, water acts on the slide only through a buoyancy term and any drag contribution is neglected.

The basal friction angle is adjusted through a sensitivity study to fit with the observed water waves at the four tide gauges that recorded the tsunami. Values of $1,2,5$ and $10^{\circ}$ were tested and results were analyzed in the near-field (Gauge 1, Figure 6a) and in the far-field (Gauge 3, Figure 6p and Gauge 6, Figure 6e). Gauges locations are presented in Figure 9 and listed in Table 1.

\subsection{Tsunami model}

As in Paris et al. (2019), tsunami generation is modeled by solving shallow water equations (Equations (4), (5) and (6)) during 80 seconds after the landslide triggering. Beyond 80 seconds, Boussinesq equations (Equations (7), (8) and (9) ) are solved in order to take into account any possible dispersive effects during the propagation. The shallow water equations solved by AVALANCHE are written as:

$$
\begin{gathered}
\frac{\partial \eta}{\partial t}+\frac{\partial(h u)}{\partial x}+\frac{\partial(h v)}{\partial y}=-\frac{\partial d}{\partial t} \\
\frac{\partial u}{\partial t}+u \frac{\partial u}{\partial x}+v \frac{\partial u}{\partial y}=-g \frac{\partial \eta}{\partial x}+F_{x} \\
\frac{\partial v}{\partial t}+u \frac{\partial v}{\partial x}+v \frac{\partial v}{\partial y}=-g \frac{\partial \eta}{\partial y}+F_{y}
\end{gathered}
$$

where $\eta$ is the surface elevation, $h=\eta+d$ the water column height, $d$ is the depth, $u$ and $v$ the depth-averaged velocities along the $x$ and $y$ axes respec- 
tively and $F_{x}$ and $F_{y}$ the friction and Coriolis forces, which are assumed to be negligible in our modeling.

Following Løvholt et al. (2008), the Boussinesq equations read:

$$
\frac{\partial \eta}{\partial t}+\frac{\partial(h u)}{\partial x}+\frac{\partial(h v)}{\partial y}=-\frac{\partial d}{\partial t} ;
$$

$$
\begin{aligned}
\frac{\partial u}{\partial t}+ & u \frac{\partial u}{\partial x}+v \frac{\partial u}{\partial y}=-g \frac{\partial \eta}{\partial x}+\frac{d^{3}}{3}\left[\frac{\partial^{2} u_{t}}{\partial x^{2}}+\frac{\partial^{2} v_{t}}{\partial x \partial y}\right] \\
& +\frac{d}{2}\left[u_{t} \frac{\partial^{2} d}{\partial x^{2}}+u_{t} \frac{\partial^{2} d}{\partial x \partial y}\right]+d \frac{\partial d}{\partial x} \frac{\partial u_{t}}{\partial x}+\frac{d}{2}\left[\frac{\partial d}{\partial x} \frac{\partial v_{t}}{\partial y}+\frac{\partial d}{\partial y} \frac{\partial v_{t}}{\partial x}\right]+F_{x}
\end{aligned}
$$

$$
\begin{aligned}
\frac{\partial v}{\partial t}+ & u \frac{\partial v}{\partial x}+v \frac{\partial v}{\partial y}=-g \frac{\partial \eta}{\partial y}+\frac{d^{3}}{3}\left[\frac{\partial^{2} v_{t}}{\partial y^{2}}+\frac{\partial^{2} u_{t}}{\partial x \partial y}\right] \\
& +\frac{d}{2}\left[v_{t} \frac{\partial^{2} d}{\partial y^{2}}+v_{t} \frac{\partial^{2} d}{\partial x \partial y}\right]+d \frac{\partial d}{\partial y} \frac{\partial v_{t}}{\partial y}+\frac{d}{2}\left[\frac{\partial d}{\partial x} \frac{\partial u_{t}}{\partial y}+\frac{\partial d}{\partial y} \frac{\partial u_{t}}{\partial x}\right]+F_{y}
\end{aligned}
$$

where $u_{t}$ and $v_{t}$ the time-derivatives of $u$ and $v$.

Both the landslide and shallow water equations, which are very similar, are solved by Godunov's finite-volume scheme, extended to second order by a Van Leer scheme (Heinrich et al., 2001a; Labbé et al. 2012). This numerical scheme was validated with an analytical solution in Mangeney et al. (2000). Boussinesq equations are solved using a finite-difference scheme for spatial derivatives together with a Crank-Nicolson scheme for the temporal discretization. This latter scheme is based on an iterative procedure that uses centered differences for linear terms and forward differences for advection terms. The implicit momentum equations are solved by alternating implicit sweeps in the $x$ and $y$ components using an ADI method (Alternating Direction Implicit). For a given direction, the dispersion terms in the other direction are discretized explicitly. For each direction ( $x$ and $y$ ), a tridiagonal matrix is then solved at each iteration, following Pedersen and Løvholt (2008).

The sea-bottom deformation due to the landslide, $\partial d / \partial t$ in Equation (7), is computed as a forcing term:

$$
\frac{\partial d}{\partial t}=\frac{1}{\cos \theta} \frac{\partial h_{s}}{\partial t}
$$


4.3 Models set-up

For simulating the landslide and tsunami in the near-field (i.e. Anak Krakatau volcano and the other islands of the Krakatau archipelago), a pre-collapse topography and bathymetry of Gouhier and Paris (2019) was used. The precollapse topography of Anak Island was derived from the DEMNAS (national digital elevation model of Indonesia, spatial resolution of 0.27 arc-second using the vertical datum EGM2008, provided by the Indonesian Geospatial Agency, and available at http://tides.big.go.id/DEMNAS/index.html). The original DEMNAS was slightly modified in order to include the latest growth of the edifice, as seen on photographs taken in August and November 20185 and satellite images (e.g. Sentinel-2 image captured on 30 September 2018, and PlanetScope image captured on 17 December 2018). Pre-collapse bathymetry is from Deplus et al. (1995). As explained in Gouhier and Paris (2019), the contour of the collapse scar was inferred from a Sentinel-1A image captured 8:30 hours after the collapse (22/12/2018 at 22:33:44 UTC) and photographs taken by Susi Air flight crew the day after (23/12/2018).

Note that the subaerial volume estimated by Gouhier and Paris (2019) likely corresponds to a minimum value because there is no data available on post-collapse bathymetry and the submarine extent of the collapse scar. Considering a slope between 5 and $8^{\circ}$ in the continuity of the subaerial landslide part, the total volume approaches 150 million $\mathrm{m}^{3}$. This volume is two times smaller than the volume of 270 million $\mathrm{m}^{3}$ modeled by Grilli et al. (2019). Pre and post-collapse topography and bathymetry around the Anak Krakatau are presented in Figures 7 and d respectively.

The bathymetric grids are built from the BATNAS one, with a spatial resolution of $180 \mathrm{~m}$ (available at http://tides.big.go.id/DEMNAS/Batnas.php). The model uses a system of multiple grids (coarse grid over deep water regions and fine grids over coastal regions) to model local effects of bathymetry. The

5 https://www.oysteinlundandersen.com/krakatau-volcano/krakatau-eruption-seenfrom-anyer-west-java-17th-november-2018/ 
parent nested grid covers the Sunda Strait, from eastern of Sumatra to western of Java Island (see Figures 1 or 9 for the grid footprint). Five child grids are used with a resolution of approximately $25 \mathrm{~m}$ : the first domain covers the Kota Agung Bay, the second the Bandar Lampung Bay, the third the Kalianda area from northern of Taman Agung to southern of Lampung, the fourth the Teluk Lada area from western of Tanjung Lesung to southern of Anjer-Kidu, and the fifth the Anjer-Kidu area from Marina Jambu to eastern of Ciwandan (grids A, B, C, D and E, respectively, see Figure 97.

\section{Results}

\section{Landslide simulation}

The sensitivity study realized on the basal friction angle shows that its influence on the generated wave heights decreases with distance. The basal friction angle plays a major role in the near-field (Gauge 1, Figure 6a) but its influence is minor in the far-field (Gauges 3 and 6, Figure 6 $\mathrm{p}$ and c). There is no significant difference between 1 and $2^{\circ}$, at least in terms of computed wave height at the coasts. Using a friction angle of $2^{\circ}$, calculated water heights are of $75 \mathrm{~cm}$ at Marina Jambu and $33 \mathrm{~cm}$ at Kota Agung, whereas observed ones are of 60 and $35 \mathrm{~cm}$ respectively. A friction angle of $10^{\circ}$ results in wave heights of 56 and $16 \mathrm{~cm}$ respectively. Based on all the tide gauges, the best fit is obtained with a friction angle of $2^{\circ}$. This low value is consistent with the one used in Giachetti et al. (2012) and other studies about landslides on volcanoes slopes (e.g. Le Friant et al. (2003) with $7^{\circ}$ for the flank collapse of Montagne Pelée (Martinique, Lesser Antilles), Kelfoun et al. (2010) with values between 3 and $5^{\circ}$ for different landslides scenarios envisaged at La Réunion Island or Giachetti et al. (2011) with values between 1.3 and $3.9^{\circ}$ for reproducing the Güìmar debris avalanche (Tenerife, Canary Islands)).

A large part of the simulated landslide collapses in about 40 seconds (Figure 8 ), the volcano summit decreasing from about $350 \mathrm{~m}$ of altitude to about $120 \mathrm{~m}$ (Figures 7 and 8), which is concordant with the topographic reconstruc- 
tion of Gouhier and Paris (2019). Beyond 40 seconds, the calculated ground displacement is negligible and no longer has any effect on the water surface deformation. The landslide covers a horizontal distance of about $4000 \mathrm{~m}$ from the volcano to the 1883 submarine caldera, with an average velocity of $35 \mathrm{~m} \cdot \mathrm{s}^{-1}$. Figure 7 shows both the numerical initial and final states of the volcano, with a cross-section illustrating the major topographic change induced by the flank collapse.

As shown by the temporal evolution of the landslide tip and the associated tsunami front (Figure 8), velocities are quite similar, which can signify efficient transfer process. But further investigation may be needed as the part of the landslide with the largest thickness situated in smaller depth may be more important for energy transfer than the slide tip, and the wave is a bit too fast to stay in contact with this area.

\section{Tsunami simulation}

Computed results are analyzed through a maximum surface elevations map (Figure 9) covering the entire domain. On the tsunami path, synthetic gauges are located at places where tide gauges recorded the tsunami, i.e. Marina Jambu and Ciwandan for Java, Kota Agung and Panjang for Sumatra (Gauges 3, 4, 6 and 7 respectively, see Figure 9 and Table 1) and results are compared with detided data (the tide filter is based on the MATLAB package T_TIDE (Pawlowicz et al., 2002) ) in Figure 10. Other synthetic gauges are used, near the volcano, at Tanjung Lesung and Kalianda (Gauges 1, 2 and 5 respectively, see Figure 9 and Table 1 in order to compare the results to the field surveys data in these areas.

During the first 20 seconds of collapse the tsunami wave is being generated until it reaches a maximum positive elevation of $80 \mathrm{~m}$ (Figure 8). Sertung Island is the first place to be hit after 80 seconds of wave propagation. It is located $3 \mathrm{~km}$ from the volcano which results in a wave celerity of about 38 $\mathrm{m} . \mathrm{s}^{-1}$. Rakata Island is hit in about the same time, with a speed of $50 \mathrm{~m} \cdot \mathrm{s}^{-1}$. Then the wave travels around the Sunda Strait and reaches Gauge 1 (5 min after the collapse, with $5.6 \mathrm{~m}$ of wave height (Figure 11) ), Gauge 2 (Tanjung 
Lesung, 29 min, $1.7 \mathrm{~m}$ (Figure 11b)), Gauge 3 (Marina Jambu, $34 \mathrm{~min}, 75$ $\mathrm{cm}$ (Figure 10 )), Gauge 4 (Ciwandan, $42 \mathrm{~min}, 22 \mathrm{~cm}$ (Figure 10b)), Gauge 5 (Kalianda, 49 min, $1.2 \mathrm{~m}$ (Figure 11k)), Gauge 6 (Kota Agung, $45 \mathrm{~min}, 33 \mathrm{~cm}$ (Figure 10k)) and Gauge 7 (Panjang, 1:06 hours, $20 \mathrm{~cm}$ (Figure 10d)).

For the first wave, simulated water heights on the synthetic gauges are quite consistent with the tide gauges records $(75 \mathrm{~cm}$ computed vs $60 \mathrm{~cm}$ recorded at Marina Jambu, $22 \mathrm{~cm}$ vs $20 \mathrm{~cm}$ at Ciwandan, $33 \mathrm{~cm}$ vs $35 \mathrm{~cm}$ at Kota Agung), excepted at Panjang (20 cm vs $37 \mathrm{~cm}$ ). In addition, according to the concert video, the height of the first water wave is estimated to be 1 to $2 \mathrm{~m}$, which is consistent with the computed water height of $1.7 \mathrm{~m}$ at Tanjung Lesung (Figure 11b, Gauge 2). However, computed arrival times are late compared to the recorded ones ( 1 min at Marina Jambu, 3 min at Ciwandan, 5 min at Kota Agung and 8 min at Panjang). The general wave pattern is well reproduced at Marina Jambu but poorly at Ciwandan, Kota Agung and Panjang.

Table 1 Summary of results sorted by arrival times. Computed (Comp.) results are compared with recorded (Rec.) data and Giachetti et al.s (2012) results. Gauges number refer to Figure 9

\begin{tabular}{|c|c|c|c|c|c|c|c|}
\hline \multirow{2}{*}{$\begin{array}{l}\text { Gauges } \\
\text { location }\end{array}$} & \multirow{2}{*}{$\begin{array}{c}\text { Coordinates } \\
\text { (Longitude , Latitude) }\end{array}$} & \multirow{2}{*}{$\frac{\text { Depth }}{(\mathbf{m})}$} & \multicolumn{3}{|c|}{ Travel time (min) } & \multicolumn{2}{|c|}{ Wave Height $(\mathrm{cm})$} \\
\hline & & & Giachetti et al. (2012) & Comp. & Rec. & Comp. & Rec. \\
\hline 1-Near the volcano & $105.31376,-6.14967$ & 100 & $\oslash$ & 5 & $\oslash$ & 560 & $\oslash$ \\
\hline 2-Tanjung Lesung & $105.64894,-6.47980$ & 1.5 & 28 & 29 & $\oslash$ & 170 & $100-200$ \\
\hline 3-Marina Jambu & $105.84263,-6.18953$ & 1.8 & 33 & 34 & 33 & 75 & 60 \\
\hline 4-Ciwandan & $105.95513,-6.01441$ & 1.1 & 42 & 42 & 39 & 22 & 20 \\
\hline 6-Kota Agung & $104.62044,-5.50120$ & 1.0 & $\oslash$ & 45 & 39 & 33 & 35 \\
\hline 5-Kalianda & $105.55701,-5.70134$ & 2.9 & 47 & 49 & $\oslash$ & 120 & $\oslash$ \\
\hline 7-Panjang & $105.29036,-5.44579$ & 1.3 & 68 & 66 & 58 & 20 & 37 \\
\hline
\end{tabular}

\section{Dispersion assessment}

In order to assess and highlight the potential dispersive effects in the Sunda Strait, shallow water simulation was performed with AVALANCHE and com- 
pared with the present Boussinesq simulation (Figure 12). Time series calculated by the two models are compared at three synthetic gauges (Gauges 1, 8 and 9, Figure 9) located in deep water at depths of 100 (Figure 12 2 ), 1140 (Figure 12b) and $1960 \mathrm{~m}$ (Figure 12c). Close to the source, both simulations produce approximately the same first water wave as depicted in Figure $12 \mathrm{a}$ with water wave heights of about $5.5 \mathrm{~m}$. However, dispersion effects are noticed in the far-field and in deep ocean. Compared to shallow water simulations, the period of the first wave increases during the propagation, ranging from about $1 \mathrm{~min}$ (Gauge 1, Figure 12a) to about $1 \mathrm{~min} 30 \mathrm{~s}$ (Gauge 8, Figure 12p) and about 2 min (Gauge 9, Figure 12 ).

\section{Discussion}

This study presents preliminary results of the 22 December 2018 Anak Krakatau collapse and tsunami simulations, comparing the computed numerical results with several observed data such as flow depths or recorded surface elevations. The main goal of this study was to better understand the landslide that occurred and assess its volume, despite the lack of submarine information. With the collapse of 150 million $\mathrm{m}^{3}$ modeled following a Coulomb frictional law, the obtained water heights are quite consistent with the observed ones, all over the Sunda Strait, and the computed amplitudes of the first wave match the tide gauges-extracted amplitudes (with errors ranging from $6 \%$ at Kota Agung to 25\% at Marina Jambu), excepted at Panjang (error of $46 \%$ ).

In comparison with the study of Grilli et al. (2019), our results (water heights and time delays of the first wave) are very similar at the four tide gauges, with water heights differences of $50 \%$ at Marina Jambu, $12 \%$ at Ciwandan, $10 \%$ at Kota Agung and $0 \%$ at Panjang. In the near-field, our results are also very similar to the time series calculated at five additional gauges used

by Grilli et al. (2019) (see Figure 9b for gauges locations). The amplitudes of the generated water wave calculated by Grilli et al. (2019) are obviously larger in the near-field since the authors consider a landslide volume of 270 million 
$\mathrm{m}^{3}$. Nevertheless, we obtain the same arrival times, periods and to a lesser extent the same wave behaviour (see Figure 13 in our paper and Figure 5 in Grilli et al. (2019)). Our results are also similar in the near-field to those of Heidarzadeh et al. (2020). Considering a forward modeling trial-error approach, the latter ones obtain a wave height of about 100 to $150 \mathrm{~m}$ with a wavelength of 1.5 to $2 \mathrm{~km}$. Their results are close to our first simulated wave characterized by a maximum amplitude of $80 \mathrm{~m}$ and a wavelength of about 2 km (see Figure 8 in this study and Figure 12 in Heidarzadeh et al. (2020)).

Table 2 and Table 3 show computed water heights at places studied by the field surveys of Takabatake et al. (2019) and the BMKG, and the KKP respectively. Although the comparison between inundation or run-up heights with water wave heights may be hard to realise, we see for instance that at Cipenyu Beach, where highest run-up values were measured, we obtain the highest water heights. The computed wave heights are a little bit shorter than the observed ones by the BMKG survey, with 3 to $4 \mathrm{~m}$ vs 5 to $6 \mathrm{~m}$. At the 5 locations close to the shoreline, i.e. distance lower than $30 \mathrm{~m}$ (Carita Lagon for BMKG survey (Table 2); Karang Suraga, Bulakan, Tanjung Jaya and Banyuasih for the KKP survey (Table 3p), the measured flow depths are on the same order that the computed tsunami height at the coast. Note that the bathymetric resolution (180 $\mathrm{m}$ interpolated to $25 \mathrm{~m}$ for the child grids) used in this study does not allow to compare precise inundation or run-up heights.

Although the results are encouraging, some limitations can be pointed out. First of all, the landslide reconstruction may be subject to discussion. It has been realized based on satellite images of the 23rd of December for the subaerial part and a quasi constant slope hypothesis for the submarine part. Unfortunately, the intense volcanic activity of the days following the tsunami has completely changed the shape of the volcano and it has made precise reconstruction impossible. Nevertheless, tsunami simulation associated to this landslide is rather consistent with observed water heights. A sensitivity study on the basal friction coefficient $\phi$ (Figure 6) suggests that these water heights 
may vary quasi linearly with $\phi$ in the near-field, the smaller the friction angle, the higher the water wave heights. In the far-field along the coasts of Java or Sumatra, differences of water heights between $\phi=1^{\circ}$ or $\phi=2^{\circ}$ are not significant.

Second, the time delays of wave arrivals at the four tide gauges (Gauges 3, 4, 6 and 7, Figure 9p could indicate that the landslide volume and its dynamics are unknown. However, sensitivity tests (not shown in this study) on the landslide volume produce similar results in terms of wave arrivals. In addition, our travel times are similar to those calculated by Giachetti et al. (2012) and Grilli et al. (2019) for landslide volumes of 280 million $\mathrm{m}^{3}$ and 270 million $\mathrm{m}^{3}$ respectively. A possible explanation would be inaccuracies of the bathymetric data in this area. Travel times should thus be interpreted carefully. More information on the landslide will be available thanks to forthcoming surveys in the caldera.

Third, this study is a first attempt of simulating the collapse of A. K. volcano using 2D depth-averaged models both for the landslide and the tsunami. Several complex phenomena are not taken into account such as mixing of the slide with the surrounding water, soil erosion or dissipation of water waves due to wave breaking or friction.

Finally, according to Glimsdal et al. (2013), the dispersive effects can be estimated using the dispersion parameter:

$$
\tau=\frac{4 h_{0}^{2} L}{\lambda^{3}}
$$

where $h_{0}$ is the depth at the source, $L$ the distance to the coast of interest and $\lambda$ the source width or in other terms the wavelength.

The dispersion parameter is $\sim 1.4$ at Kalianda up to $\sim 3.4$ at Kota Agung, with $h_{0}=250 \mathrm{~m}, L$ between 45 and $110 \mathrm{~km}$ (see Table 1) and $\lambda=2000 \mathrm{~m}$ (see Figure 8b), and suggests that the propagation is highly dispersive. Results of the comparison between the shallow water and Boussinesq simulations (Figure 12 confirm that the first wave is subjected to dispersion, losing highfrequency components and being stretched by dispersive effects. After $25 \mathrm{~min}$ of propagation in deep ocean (Figure 12 ), the period is approximately two times longer and the amplitude decreases by about $50 \%$ compared to the one 
calculated by the shallow water model. The use of the Boussinesq model in this study is therefore relevant.

\section{Conclusion}

The 22 December, 2018 Anak Krakatau southwestern flank collapse is modeled by a 2D depth-integrated code with a Coulomb frictional law and a basal friction angle of $2^{\circ}$. The generated tsunami is propagated using a Boussinesq model. This study highlighted some points and revealed some issues:

- The computed water heights from the present modeling fit well with those recorded at tide gauges of Marina Jambu, Ciwandan and Kota Agung (errors of $25 \%, 10 \%$ and $6 \%$ respectively), with the video recorded at Tanjung Lesung and with the different observed data from the KKP, BMKG and Takabatake et al. (2019) field surveys.

- Results presented in this study are very similar to those obtained by Grilli et al. (2019) both in the near-field and in the far-field. However, their model is $3 \mathrm{D}$, suggesting proper representation of the governing processes in both studies. Heights and wavelengths of the first wave are also very close to those obtained by Heidarzadeh et al. (2020) in the near-field.

- Delays between simulated and observed travel times may be attributed to inaccuracies in the bathymetric data, particularly in the Bandar Lampung Bay.

- Despite the lack of submarine information at the bottom of the volcano, the collapse of the reconstructed volume of 150 million $\mathrm{m}^{3}$ produces water waves that fit well with the observed results.

- The sensitivity study on the basal friction angle shows that its influence on the generated wave heights decreases with distance and that there are no significant differences of water heights between basal friction coefficients of 1 or $2^{\circ}$.

- Finally, a comparison between a Boussinesq model and a shallow water propagation highlights dispersive effects in the Sunda Strait that appear to 
be significant for the first waves. In deep waters, their periods progressively increase whereas their amplitudes progressively decrease.

Acknowledgements We thank Abdul Muhari, from the Directorate of Sustainable Utilization of Coastal Zone and Small Islands, Ministry of Marine Affairs and Fisheries, Indonesia, for providing us with the tide gauges data and the KKP field survey data, and Gegar Prasetya, for providing us the BMKG field survey data. 
Table 2 Computed water heights (W.H.) (m) at the shoreline compared with flow depths (F.D.), inundation heights (I.H.) and run-up heights (R.H.) identified by the Takabatake et al. (2019) and BMKG surveys. Values in parenthesis are the distances from the shoreline. Values in brackets are the maximum inundation distances measured by the different team surveys.

\begin{tabular}{|c|c|c|c|c|c|}
\hline Places & Coordinates & W.H. (m) & F.D. $(\mathbf{m})$ & I.H. (m) & R.H. (m) \\
\hline & Longitude, Latitude & Computed & \multicolumn{3}{|c|}{ Takabatake et al.'s (2019) Survey } \\
\hline Sinar Agung & $105.10208,-5.77083$ & 0.4 & & $2.35(10)$ & \\
\hline Sinar Agung & $105.10128,-5.77061$ & 0.4 & & $1.58(20)$ & \\
\hline Bandung Jaya & $105.10533,-5.77611$ & 0.4 & & $0.81(0)$ & \\
\hline Bandung Jaya & $105.10936,-5.77353$ & 0.5 & & $1.74(36)$ & \\
\hline Selesung & $105.29231,-5.80242$ & 0.4 & & $3.38(15)$ & \\
\hline Selesung & $105.29231,-5.80261$ & 0.4 & & $3.38(31)$ & \\
\hline Central Waymuli & $105.63419,-5.83739$ & 0.6 & & & $5.04(75)$ \\
\hline East Waymuli & $105.64164,-5.83558$ & 1.2 & & & $3.97(79)$ \\
\hline Kunjir & $105.65161,-5.83592$ & 0.9 & & $4.21(76)$ & \\
\hline Kahai Beach & $105.66814,-5.83789$ & 2.3 & & $6.83(22)$ & \\
\hline Tangkolo & $105.82944,-6.26461$ & 1.3 & & $1.01(198)$ & \\
\hline Lantera & $105.82314,-6.37628$ & 1.9 & & $3.36(39)$ & \\
\hline Cipenyu Beach & $105.64139,-6.50536$ & 2.7 & & & $12.58(185)$ \\
\hline Cipenyu Beach & $105.64083,-6.50417$ & 2.7 & & $11.28(85)$ & \\
\hline Cipenyu Beach & $105.64108,-6.50419$ & 2.7 & & $10.17(114)$ & \\
\hline Tanjung Jaya & $105.62436,-6.54508$ & 2.5 & & $5.39(170)$ & \\
\hline \multirow[t]{2}{*}{ Babakanciberber } & $105.61847,-6.60589$ & 0.9 & & & $2.55(48)$ \\
\hline & & & \multicolumn{3}{|c|}{ BMKG Survey } \\
\hline Tanjung Lesung & $105.65463,-6.48015$ & 3 & & $5.06(60)[303.31]$ & \\
\hline Tanjung Lesung & $105.65453,-6.48010$ & 3 & $4.23(50)[303.31]$ & & \\
\hline Mutiara Carita & $105.83200,-6.31613$ & 3 & & $3.05(24)[170.28]$ & \\
\hline Mutiara Carita & $105.83200,-6.31644$ & 3 & $2.9(55)$ [170.28] & & \\
\hline Mutiara Carita & $105.83018,-6.31634$ & 2.4 & & $5.08(14)[170.28]$ & \\
\hline Mutiara Carita & $105.82907,-6.31728$ & 3 & & $5.04(10)[170.28]$ & \\
\hline Mutiara Carita & $105.82828,-6.31876$ & 3.4 & & $5.64(12)[170.28]$ & \\
\hline Mutiara Carita & $105.82828,-6.31996$ & 4.3 & & $6.22(14)[170.28]$ & \\
\hline Carita Lagon & $105.82678,-6.28562$ & 2.5 & 3.05 (18) [95.90] & & \\
\hline
\end{tabular}


Table 3 Computed water heights (W.H.) (m) at the shoreline compared with flow depths (F.D.), inundation heights (I.H.) and run-up heights (R.H.) identified by the KKP survey. Values in parenthesis are the distances from the shoreline. Values in brackets are the maximum inundation distances measured by the different team surveys.

\begin{tabular}{|c|c|c|c|c|c|}
\hline Places & Coordinates & W.H. (m) & F.D. (m) & I.H. (m) & R.H. (m) \\
\hline & Longitude , Latitude & Computed & \multicolumn{3}{|c|}{ KKP Survey } \\
\hline Karang Suraga & $105.85470,-6.15110$ & 0.8 & & & $3.74(31)[84.47]$ \\
\hline Karang Suraga & $105.84969,-6.16902$ & 0.8 & & & $3.29(51)[57.76]$ \\
\hline Karang Suraga & $105.84697,-6.17453$ & 0.9 & $0.81(26)$ & & \\
\hline Karang Suraga & $105.84747,-6.17476$ & 0.9 & & & $4.54(85)$ [94.64] \\
\hline Bulakan & $105.83830,-6.19698$ & 0.8 & $0.63(-21)$ & & \\
\hline Bulakan & $105.83619,-6.20232$ & 1.2 & & & $5.8(90)$ [124.13] \\
\hline Umbul Tanjung & $105.82577,-6.23888$ & 1.8 & & & $5.34(64)[68.8]$ \\
\hline Sukarame & $105.82887,-6.26210$ & 1.2 & $3.2(15)$ & & $4.57(15)[330]$ \\
\hline Sukarame & $105.82698,-6.27677$ & 1.6 & & & 3.45 (105) [158.92] \\
\hline Sukarame & $105.82700,-6.27700$ & 1.6 & $1.14(94)$ & & \\
\hline Tanjung Jaya & $105.65939,-6.48078$ & 3 & & & $7.07(74)[158.84]$ \\
\hline Tanjung Jaya & $105.65935,-6.48047$ & 3 & $1.65(64)$ & & \\
\hline Tanjung Jaya & $105.65940,-6.48005$ & 3 & $3.1(18)$ & & \\
\hline Tanjung Jaya & $105.65817,-6.47995$ & 3 & $1.23(37)$ & & \\
\hline Tanjung Jaya & $105.65817,-6.48033$ & 3 & $0.77(77)$ & & \\
\hline Cipenyu Beach & $105.64078,-6.50363$ & 2.7 & $1.3(90)$ & & \\
\hline Cipenyu Beach & $105.64101,-6.50466$ & 2.7 & $2.24(117)$ & & \\
\hline Cipenyu Beach & $105.64165,-6.50461$ & 2.7 & $1.51(186)$ & & \\
\hline Cipenyu Beach & $105.63815,-6.50781$ & 2.1 & & & $8.51(42)$ [66.59] \\
\hline Pantai Legon & $105.63335,-6.51699$ & 2.3 & & & $13.49(42)[124.58]$ \\
\hline Tanjung Jaya & $105.62888,-6.52415$ & 2.6 & & & $10.94(97)[159.42]$ \\
\hline Tanjung Jaya & $105.62673,-6.5296$ & 2.8 & & & $13.2(154)[121.83]$ \\
\hline Pantai Batu & $105.62356,-6.54209$ & 1.2 & $1.54(62)$ & & \\
\hline Banyuasih & $105.62223,-6.55211$ & 2.5 & $1.82(63)$ & & \\
\hline Banyuasih & $105.61664,-6.56774$ & 1.8 & $5.40(11)$ & & \\
\hline Banyuasih & $105.61785,-6.56787$ & 1.8 & $1.25(144)$ & & \\
\hline Banyuasih & $105.61800,-6.56839$ & 1.8 & $0.43(176)$ & & \\
\hline
\end{tabular}




\section{References}

Abadie, S., Harris, J., Grilli, S. and Fabre, R. (2012), 'Numerical modeling of tsunami waves generated by the flank collapse of the Cumbre Vieja Volcano (La Palma, Canary Islands): Tsunami source and near fiedl effects', Journal of Geophysical Research 117(5).

Assier-Rzadkiewicz, S., Heinrich, P., Sabatier, P., Savoye, B. and Bourillet, J. (2000), 'Numerical modelling of a landslide-generated tsunami: The 1979 Nice event', Pure and Applied Geophysics 157(10), 1707-1727.

Bondevik, S., Løvholt, F., Harbitz, C., Mangerud, J., Dawson, A. and Svendsen, J. (2005), 'The Storegga slide tsunami - comparing field observations with numerical simulations', Marine and Petroleum Geology 22, 195-208.

Camus, G., Gourgaurd, A. and Vincent, P. (1987), 'Petrologic evolution of Krakatau (Indonesia): implications for a future activity', Journal of Volcanology and Geothermal Research 33, 299-316.

Choi, B., Pelinovsky, E., Kim, K. and Lee, J. (2003), 'Simulation of the transoceanic tsunami propagation due to the 1883 Krakatau volcanic eruption', Natural Hazards and Earth System Science, Copernicus Publications on behalf of the European Geosciences Union 3(5), 321-332.

Cooke, R. (1981), 'Eruptive history of the volcano at Ritter Island', Geological Survey of Papua New Guinea Memoir 10, 115-123.

Deplus, C., Bonvalot, S., Dahrin, D., Diament, M., Harjono, H. and Dubois, J. (1995), 'Inner structure of the Krakatoa volcanic complex (Indonesia) from gravity and bathymetry data', Journal of Volcanology and Geothermal Research 64, 23-51.

Fine, I. V., Rabinovich, A. B., Thomson, R. E. and Kulikov, E. A. (2003), Numerical Modeling of Tsunami Generation by Submarine and Subaerial Landslides, Springer Netherlands, Dordrecht, pp. 69-88.

Franz, M., Jaboyedoff, M., Locat, J. and Podladchikov, Y. (2015), Testing a landslide-generated tsunami model. The case of the Nicolet landslide (Québec, Canada), in 'Conference GEOQuébec 2015', Québec City, QC, 
Canada.

Fritz, H., Mohammed, F. and Yoo, J. (2009), 'Lituya Bay landslide impact generated mega-tsunami 50th anniversary', Pure and Applied Geophysics 166, $153-175$.

Giachetti, T., Paris, R., Kelfoun, K. and Ontowirjo, B. (2012), 'Tsunami hazard related to a flank collapse of Anak Krakatau volcano, Sunda Strait, Indonesia', Geological Society Londo, Special Publication 361, 79-89.

Giachetti, T., Paris, R., Kelfoun, K. and Pérez-Torrado, F. (2011), 'Numerical modelling of the tsunami triggered by the Güimar debris avalanche, Tenerife (Canary Islands): Comparison with field-based data', Marine Geology 284, 189-202.

Glimsdal, S., L'Heureux, J.-S., Harbitz, C. and Løvholt, F. (2016), 'The 29th January 2014 submarine landslide at Statland, Norway-landslide dynamics, tsunami generation, and run-up', Landslides 13(6), 1435-1444.

Glimsdal, S., Pedersen, G., Harbitz, C. and Løvholt, F. (2013), 'Dispersion of tsunamis: doest it really matter?', Natural Hazards and Earth System Sciences 13, 1507-1526.

Gouhier, M. and Paris, R. (2019), 'SO2 and tephra emissions during the December 22, 2018 Anak Krakatau flank-collapse eruption', Volcanica 2(2), 91103.

Grilli, S., O’Reilley, C., Harris, J., Tajalli Bakhsh, T., B., T., Banihashemi, S., Kirby, J., Baxter, C., Eggeling, T., Ma, G. and Shi, F. (2015), 'Modeling of SMF tsunami hazard along the upper US East Coast: detailed impact around Ocean City, MD', Natural Hazards 76, 705-746.

Grilli, S., Tappin, D., Carey, S., Watt, S., Ward, S., Grilli, A., Engwell, S., Zhang, C., Kirby, J., Schambach, L. and Muin, M. (2019), 'Modelling of the tsunami from the December 22, 2018 lateral collapse of Anak Krakatau volcano in the Sunda Straits, Indonesia', Scientific Reports 9(11946).

Grilli, S. and Watts, P. (2005), 'Tsunami generation by submarine mass failure. I: Modeling, experimental validation, and sensitivity analyses', Journal of Waterway, Port, Coastal and Ocean Engineering 131(6), 283-297. 
Haflidason, H., Sejrup, H., Nygard, A., Meinert, J., Bryn, P., Lien, R., Forsberg, C., Berg, K. and Masson, D. (2004), 'The Storegga slide: architecture, geometry and slide development', Marine Geology 213(1-4), 201-234.

Harbitz, C. (1992), 'Model simulations of tsunamis generated by the Storegga slides', Marine Geology 105(1-4), 1-21.

Harbitz, C., Glimsdal, S., Løvholt, F., Kveldsvik, V., Pedersen, G. and Jensen, A. (2014), 'Rockslide tsunamis in complex fjords: From an unstable rock slope at Åkerneset to tsunami risk in western Norway', Coastal Engineering 88, 101-122.

Harbitz, C., Pedersen, G. and Gjevik, B. (1993), 'Numerical simulations of large water waves due to landslides', Journal of Hydraulic Engineering $\mathbf{1 1 9}(12), 1325-1342$.

Harjono, H., Diament, M., Dubois, J. and Larue, M. (1991), 'Seismicity of the Sunda strait: evidence for crustal extension and volcanological implications', Tectonics 10, 17-30.

Heidarzadeh, M., Ishibe, T., Sandanbata, O., Muhari, A. and Wijanarto, A. (2020), 'Numerical modeling of the subaerial landslide source of the 22 December 2018 Anak Krakatoa volcanic tsunami, Indonesia', Ocean Engineering 195.

Heidarzadeh, M., Krastel, S. and Yalçiner, A. (2014), The State-of-the-Art Numerical Tools for Modeling Landslide Tsunamis: A Short Review, in S. Krastel, J.-H. Behrmann, D. Völker, M. Stipp, C. Berndt, R. Urgeles, J. Chaytor, K. Huhn, M. Strasser and C. Harbitz, eds, 'Submarine Mass Movements and Their Consequences: 6th International Symposium', Springer International Publishing, Cham, pp. 483-495.

Heinrich, P., Boudon, G., Komorowski, J. C., Sparks, R. S. J., Herd, R. and Voight, B. (2001b), 'Numerical simulation of the December 1997 Debris Avalanche in Montserrat, Lesser Antilles', Geophysical Research Letters 28(13), 2529-2532.

Heinrich, P. and Piatanesi, A. (2000), 'Near-field modeling of the July 17, 1998 tsunami in Papua New Guinea', Geophysical Research Letters 27(19), 3037- 
3040.

Heinrich, P., Piatanesi, A. and Hébert, H. (2001a), 'Numerical modelling of tsunami generation and propagation from submarine slumps: The 1998 Papua New Guinea event', Geophysical Journal International 145(1), 97111.

Horrillo, J., Wood, A., Kim, G.-B. and Parambath, A. (2013), 'A simplified 3D Navier-Stokes numerical model for landslide-tsunami: Application to the Gulf of Mexico', Journal of Geophysical Research: Oceans 118(12), 69346950 .

Huang, B., Yin, Y., Wang, S., Tan, J. and Liu, G. (2017), 'Analysis of the Tangjiaxi landslide-generated waves in the Zhexi Reservoir, china, by a granular flow coupling model', Natural Hazards and Earth System Sciences 17, 657-670.

Hébert, H., Piatanesi, A., Heinrich, P. and Schindelé, F. (2002), 'Numerical modeling of the September 13, 1999 landslide and tsunami on Fatu Hiva Island (French Polynesia)', Geophysical Research Letters 29(10), 10-13.

Jiang, L. and LeBlond, P. (1992), 'The coupling of a submarine slide and the surface waves which it generates', Journal of Geophysical Research: Oceans 97(C8), 12731-12744.

Johnson, R. (1987), 'Large-scale volcanic cone collapse; the 1888 slope failure of Ritter volcano', Bulletin of Volcanology 49, 669-679.

Kelfoun, K., Giachetti, T. and Labazuy, P. (2010), 'Landslide-generated tsunamis at Réunion Island', Journal of Geophysical Research: Earth Surface $\mathbf{1 1 5}(\mathrm{F} 4)$.

Kirby, J., Shi, F., Nicolsky, D. and Misra, S. (2016), 'The 27 April 1975 Kitimat, British Columbia, submarine landslide tsunami: a comparison of modeling approaches', Landslides 13, 1421-1434.

Labbé, M., Donnadieu, C., Daubord, C. and Hébert, H. (2012), 'Refined numerical modeling of the 1979 tsunami in Nice (French Riviera): Comparison with coastal data', Journal of Geophysical Research: Earth Surface 117(F1). 
Le Friant, A., Heinrich, P., Deplus, C. and Boudon, G. (2003), 'Numerical simulation of the last flank-collapse event of Montagne Pelée, Martinique, Lesser Antilles', Geophysical Research Letters 30(2).

L'Heureux, J.-S., Glimsdal, S., Longva, O., Hansen, L. and Harbitz, C. (2011), 'The 1888 shoreline landslide and tsunami in Trondheimsfjorden, central Norway', Marine Geophysical Research 32(1), 313-329.

Liu, P.-F., Woo, S.-B. and Cho, Y.-S. (1998), 'Computer Programs for Tsunami Propagation and Inundation', Cornell University 25.

Løvholt, F., Pedersen, G. and Gisler, G. (2008), 'Oceanic propagation of a potential tsunami from the La Palma Island', Journal of Geophysical Research: Oceans 113(9), 1-21.

Ma, G., Kirby, J., Hsu, T.-J. and Shi, F. (2015), 'A two-layer granular landslide model for tsunami wave generation: Theory and computation', Ocean Modelling 93, 40-55.

Ma, G., Shi, F. and Kirby, J. (2012), 'Shock-capturing non-hydrostatic model for fully dispersive surface wave processes', Ocean Modelling 43-44, 22-35.

Mangeney, A., Heinrich, P. and Roche, R. (2000), 'Analytical Solution for Testing Debris Avalanche Numerical Models', 157, 1081-1096.

Masson, D., Harbitz, C., Wynn, R., Pedersen, G. and Løvholt, F. (2006), 'Submarine landslides: processes, triggers and hazard prediction', Philosophical Transactions of the Royal Society A: Mathematical, Physical and Engineering Sciences 364(1845), 2009-2039.

Miller, D. J. (1960), 'Giant waves in Lituya Bay, Alaska', US Geological Survey Professional Paper 354-C.

Muhari, A., Heidarzadeh, M., Susmoro, H., Nugroho, H., Kriswati, E., Supartoyo, Wijanarto, A., Imamura, F. and Arikawa, T. (2019), 'The December 2018 Anak Krakatau Volcano Tsunami as Inferred from Post-Tsunami Field Surveys and Spectral Analysis', Pure and Applied Geophysics .

Nishimura, S., Nishida, J., Yokoyama, T. and Hehuwat, F. (1986), 'Neotectonics of the Straits of Sunda, Indonesia', Journal of Southeast Asian Earth Science 1, 81-91. 
Nomanbhoy, N. and Satake, K. (1995), 'Generation mechanism of tsunamis from the 1883 Krakatau eruption', Geophysical Reasearch Letters 22(4), 509-512.

Okal, E. A. and Synolakis, C. E. (2003), 'A theoretical comparison of tsunamis from dislocations and landslides', Pure and Applied Geophysics 160(1011), 2177-2188.

Paris, A., Okal, E., Guérin, C., Heinrich, P., Schindelé, F. and Hébert, H. (2019), 'Numerical modeling of the June 17, 2017 landslide and tsunami events in Karrat Fjord, west Greenland', Pure and Applied Geophysics $\mathbf{1 7 6}(7), 3035-3057$.

Pawlowicz, R., Beardsley, B. and Lentz, S. (2002), 'Classical tidal harmonic analysis including error estimates in MATLAB using T_TIDE', Computers and Geosciences 28, 929-937.

Pedersen, G. and Løvholt, F. (2008), 'Documentation of a global Boussinesq solver', Preprint series in Applied Mathematics 1 .

URL: http://urn.nb.no/URN:NBN:no-27r75

Poupardin, A., Heinrich, P., Frère, A., Imbert, D., Hébert, H. and Flouzat, M. (2017), 'The 1979 Submarine Landslide-Generated Tsunami in Mururoa, French Polynesia', Pure and Applied Geophysics 174, 3293-3311.

Rodriguez, M., Chamot-Rooke, N., Hébert, H., Fournier, M. and Huchon, P. (2013), 'Owen Ridge deep-water submarine landslides: Implications for tsunami hazard along the Oman coast', Natural Hazards and Earth System Science 13, 417-424.

Satake, K. and Kato, Y. (2001), 'The 1741 Oshima-Oshima eruption: extent and volume of submarine debris avalanche', Geophysical Research Letters 28, 427-430.

Satake, K., Smith, J. and Shinozaki, K. (2002), 'Three-dimensional reconstruction and tsunami model of the Nuuanu and Wailau giant landslides, Hawaii', American Geophysical Union Geophysical Monograph Series pp. 333-346.

Savage, S. B. and Hutter, K. (1989), 'The motion of a finite mass of granular material down a rough incline', Journal of Fluid Mechanics 199, 177-215. 
Savage, S. B. and Hutter, K. (1991), 'The dynamics of avalanches of granular materials from initiation to runout. Part I: Analysis', Acta Mechanica 86(1), 201-223.

Shi, F., Kirby, J., Harris, J., Geiman, J. and Grilli, S. (2012), 'A high-order adaptive time-stepping TVD solver for Boussinesq modeling of breaking waves and coastal inundation', Ocean Modelling 43-44, 36-51.

Sigurdsson, H., Carey, S., Mandeville, C. and Bronto, S. (1991), 'Pyroclastic flows of the 1883 Krakatau eruption', Eos Transactions of the American Geophysical Union 72(36), 377-392.

Simkin, T. and Fiske, R. (1983), Krakatau 1883: The Volcanic Eruption and its Effects, Smithsonian Inst. Press, Washington, D.C.

Skvortsov, A. and Bornhold, B. (2007), 'Numerical simulation of the landslidegenerated tsunami in Kitimat Arm, British Columbia, Canada, 27 April 1975', Journal of Geophysical Research: Earth Surface 112(2).

Stehn, C. (1929), The geology and volcanism of the Krakatau Group, in 'Proceedings of the Fourth Pacific Science Congress', pp. 1-55.

Sudradjat, A. (1982), 'The morphological development of Anak Krakatau Volcano, Sunda Strait', Geologi Indonesia 9, 1-11.

Susilohadi, S., Gaedicke, C. and Djajadihardja, D. (2009), 'Structures and sedimentary deposition in the Sunda Strait, Indonesia', Tectonophysics 467, 5571.

Synolakis, C. E., Bardet, J.-P., Borrero, J. C., Davies, H. L., Okal, E. A., Silver, E. A., Sweet, S. and Tappin, D. R. (2002), The slump origin of the 1998 Papua New Guinea tsunami, in 'Proceedings of the Royal Society of London, Series A: Mathematical, Physical and Engineering Sciences', Vol. 458, The Royal Society, pp. 763-789.

Takabatake, T., Shibayama, T., Esteban, M., Achiari, H., Nurisman, N., Gelfi, M., Tarigan, T., Kencana, E., Fauzi, M., Panalaran, S., Harnantyari, A. and Kyaw, T. (2019), 'Field survey and evacuation behaviour during the 2018 Sunda Strait tsunami', Coastal Engineering Journal pp. 1-21. 
Tappin, D., Grilli, S., Harris, J., Geller, R., Masterlark, T., Kirby, J., Shi, F., Ma, G., Thingbaijam, K. and Mai, P. (2014), 'Did a submarine landslide contribute to the 2011 Tohoku tsunami?', Marine Geology 357, 344-361.

Tappin, D., Watts, P. and Grilli, S. (2008), 'The Papua New Guinea tsunami of 17 July 1998: anatomy of a catastrophic event', Natural Hazards and Earth System Sciences 8, 243-266.

TDMRC (2019), 'The latest update from post-Sunda Strait tsunami survey'.

URL: http://tdmrc.unsyiah.ac.id/the-latest-update-from-post-sunda-straittsunami-survey/

Walter, T., Haghighi, M., Schneider, F., Coppola, D., Motagh, M., Saul, J., Babeyko, A., Dahm, T., Troll, V., Tilmann, F., Heimann, S., Valade, S., Triyono, R., Khomarudin, R., Kartadinata, N., Laiolo, M., Massimetti, F. and Gaebler, P. (2019), 'Precursors and processes culminating in the Anak Krakatau December 2018 sector collapse and tsunami', Nature Communications . in revision.

Wang, X. and Liu, P.-F. (2006), 'An analysis of 2004 Sumatra earthquake fault plane mechanisms and Indian Ocean tsunami', Journal of Hydraulic Research 44, 147-154.

Yavari-Ramshe, S. and Ataie-Ashtiani, B. (2016), 'Numerical modeling of subaerial and submarine landslide-generated tsunami waves-recent advances and future challenges', Landslides 13, 1325-1368. 


\section{Figures}

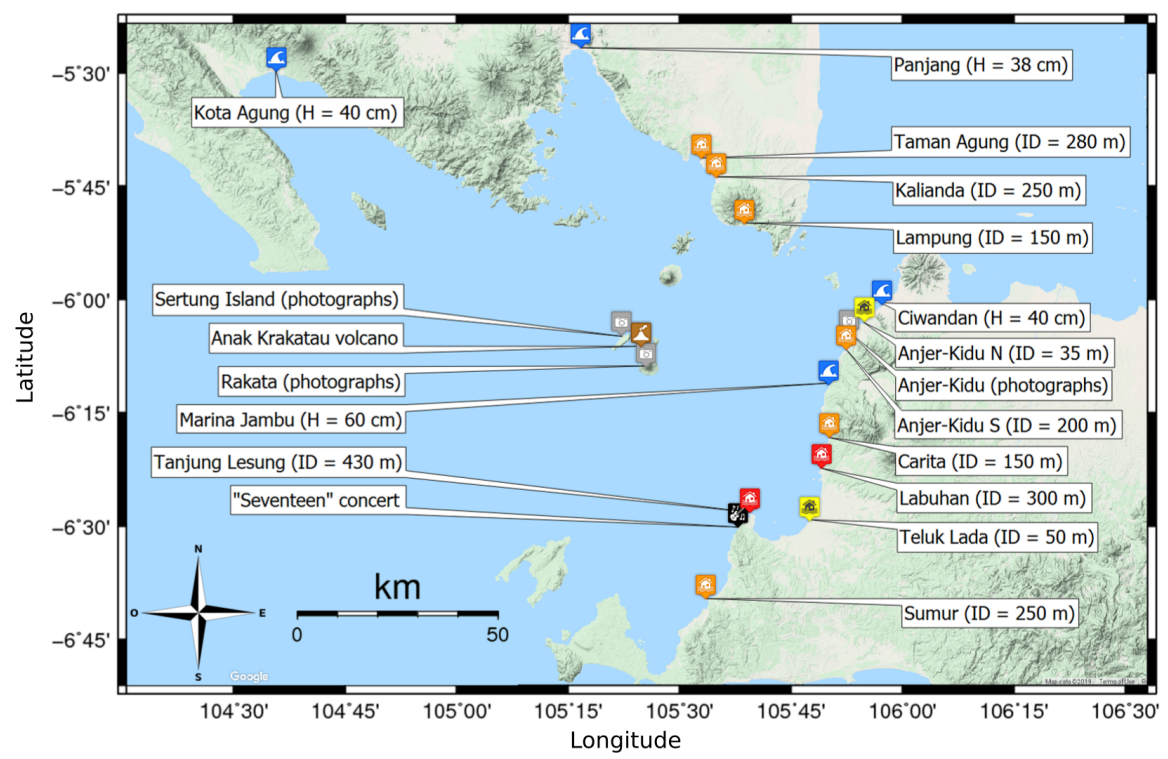

Fig. 1 Location map of Anak Krakatau volcano in the Sunda Strait (brown volcano icon) and of the different observations of the event: inundation distance $I D$ (less than $100 \mathrm{~m}$ in yellow, between 100 and $300 \mathrm{~m}$ in orange and more than $300 \mathrm{~m}$ in red), recorded height $H$ at tide gauges (blue icons) and photographs (grey icons). 

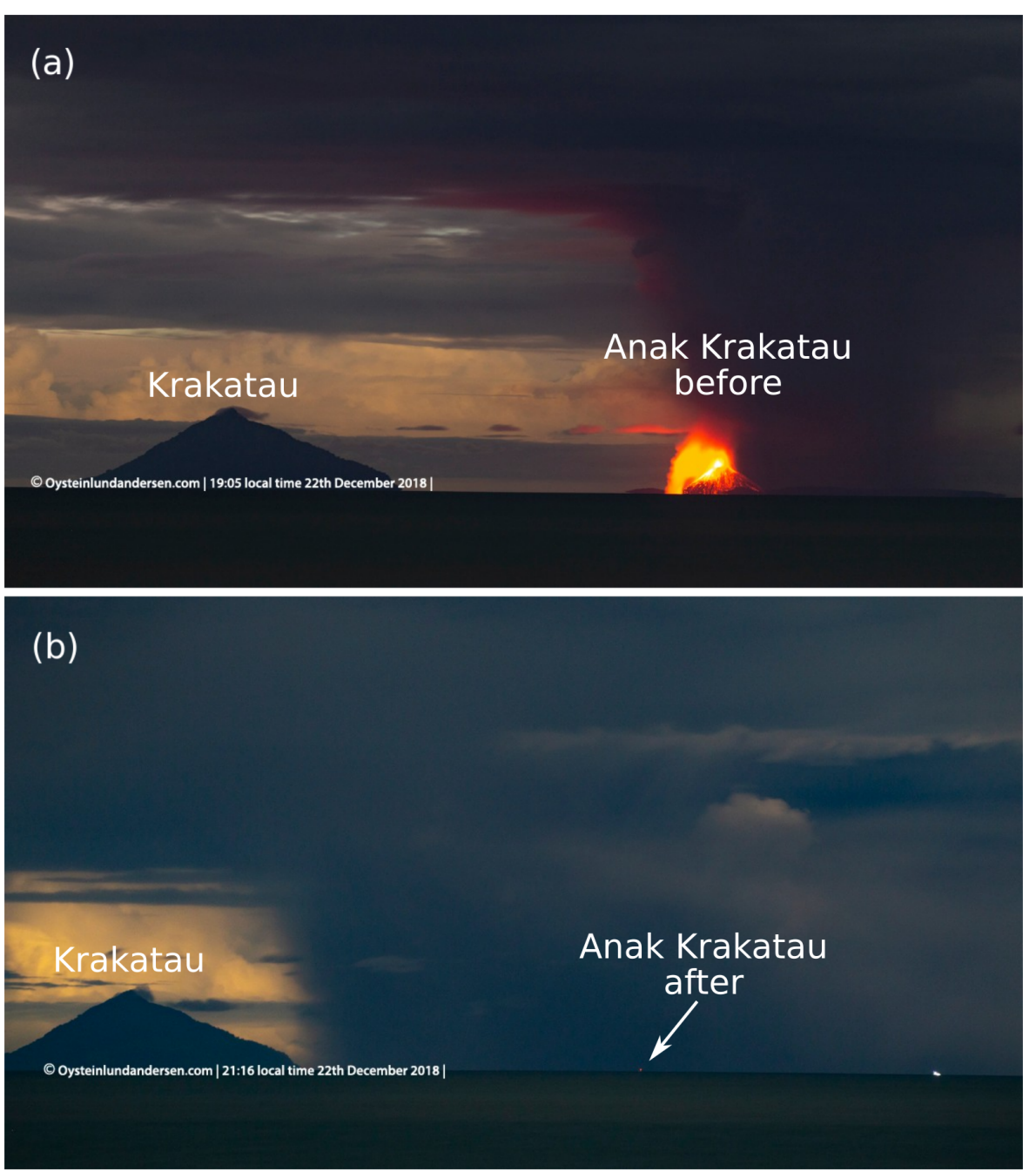

Fig. 2 Photographs taken in Anjer-Kidu, $50 \mathrm{~km}$ east of the volcano, a before the landslide at 19:05 local time and $\mathbf{b}$ after the landslide at 21:16 local time (https://www.oysteinlundandersen.com/krakatau-volcano-witnessing-the-eruptiontsunami-22december2018/). 

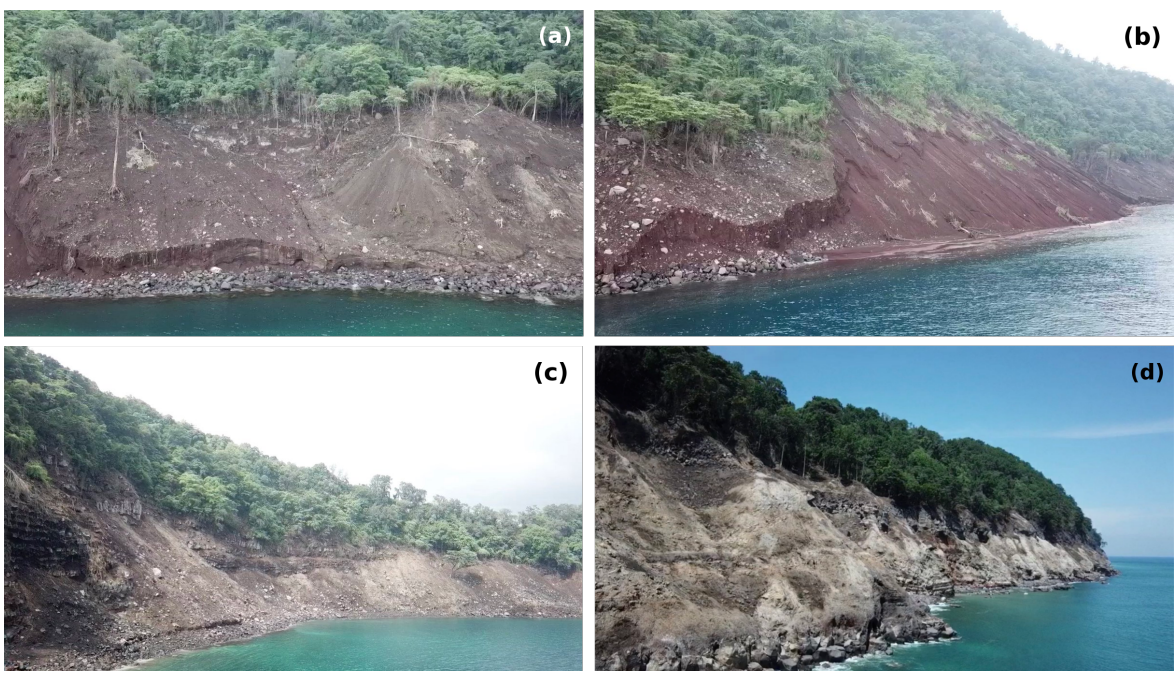

Fig. 3 Photographs of inundation effects in the near-field on $\mathbf{a}, \mathbf{b}, \mathbf{c}$ Rakata Island and $\mathbf{d}$ Sertung Island (Figure 1), close to the Anak Krakatau volcano (James Reynolds @EarthUncutTV on Twitter: https://twitter.com/earthuncuttc/status/1083305942228160513). The base of trees is estimated to be now 25 to $30 \mathrm{~m}$ above sea level.

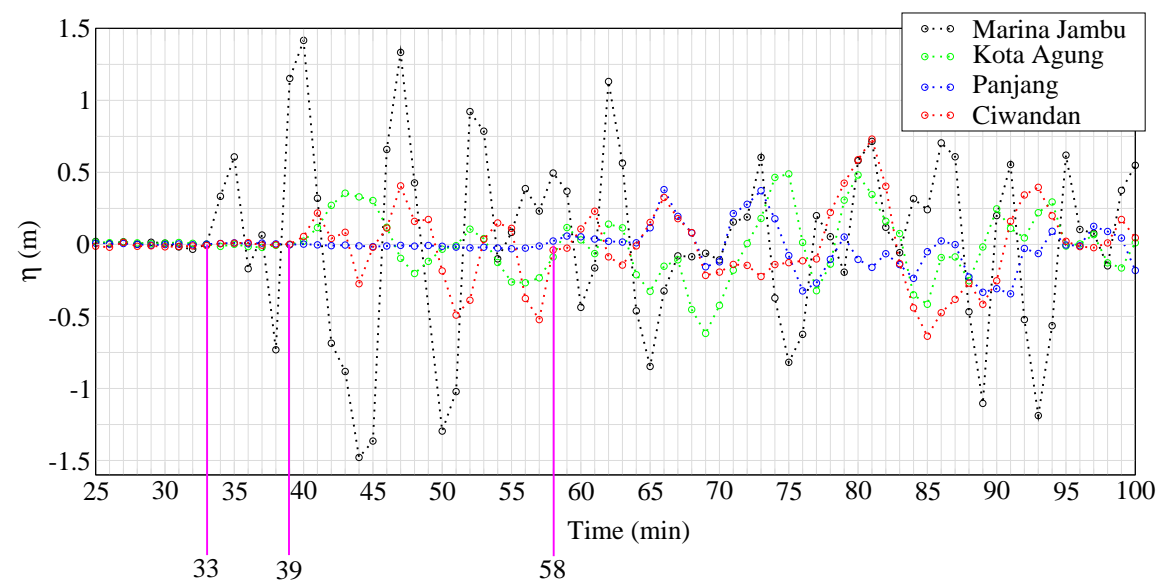

Fig. 4 Time series of surface elevation recorded by tide gauges at Marina Jambu (black), Ciwandan (red), Kota Agung (green) and Panjang (blue) tide gauges (see Figure 9 for locations). Pink lines mark the arrival times at each tide gauges. The arrival times at Kota Agung and Ciwandan are identical. 


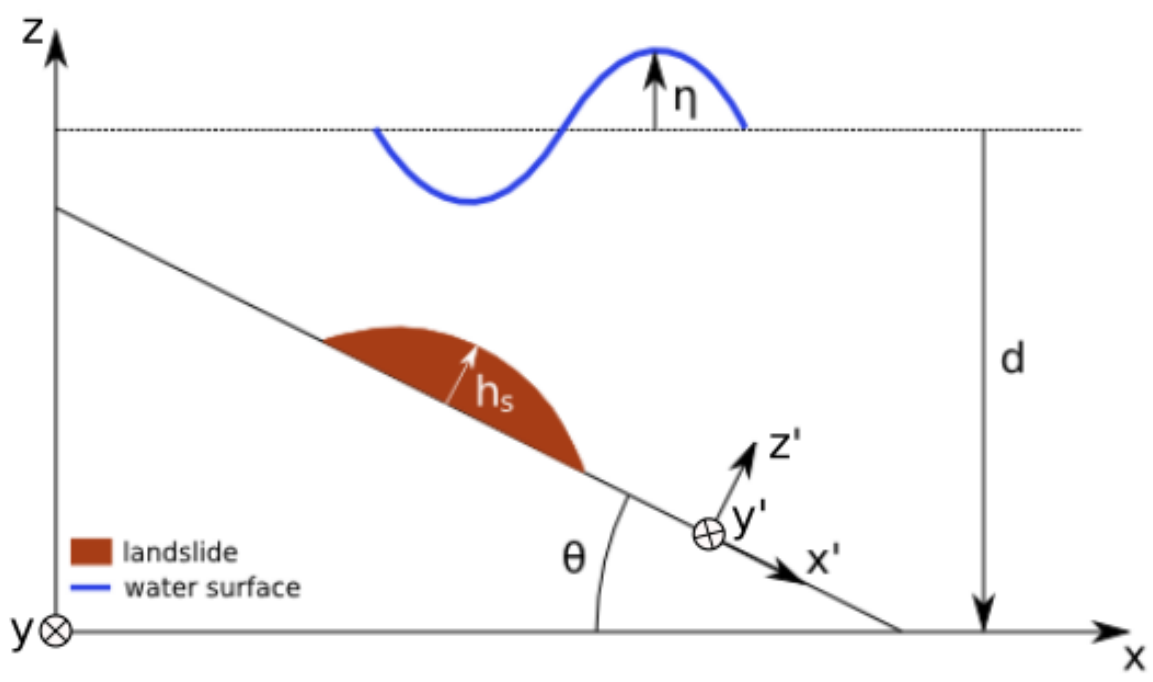

Fig. 5 Definition of parameters used in the AVALANCHE model, with $h_{s}$ the slide's thickness, $\eta$ the surface elevation, $d$ the depth and $\theta$ the local steepest slope angle. 

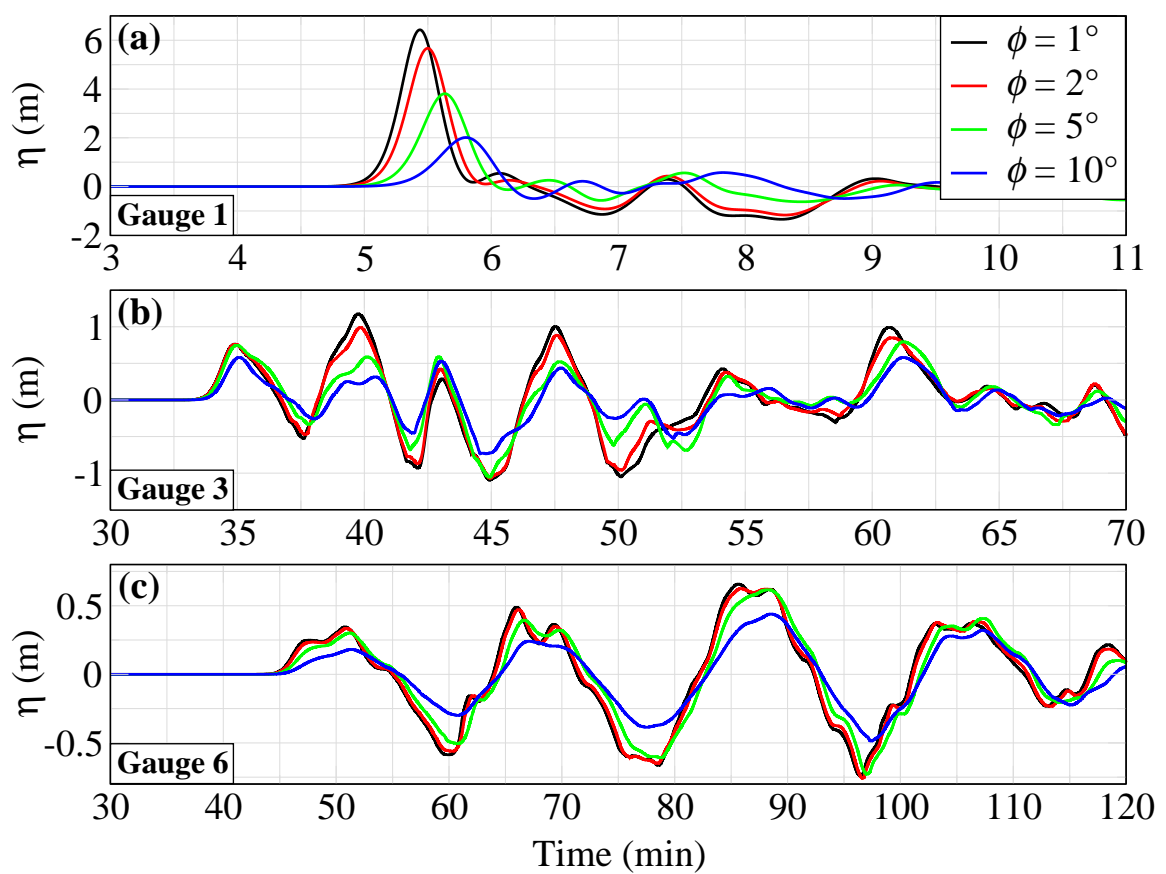

Fig. 6 Time series calculated a at Gauge 1 near the Anak Krakatau volcano, b at Marina Jambu tide gauge (Gauge 3) and c at Kota Agung tide gauge (Gauge 6), using friction angles $\phi$ of $1^{\circ}$ (black line), $2^{\circ}$ (red line), $5^{\circ}$ (green line) and $10^{\circ}$ (blue line). 

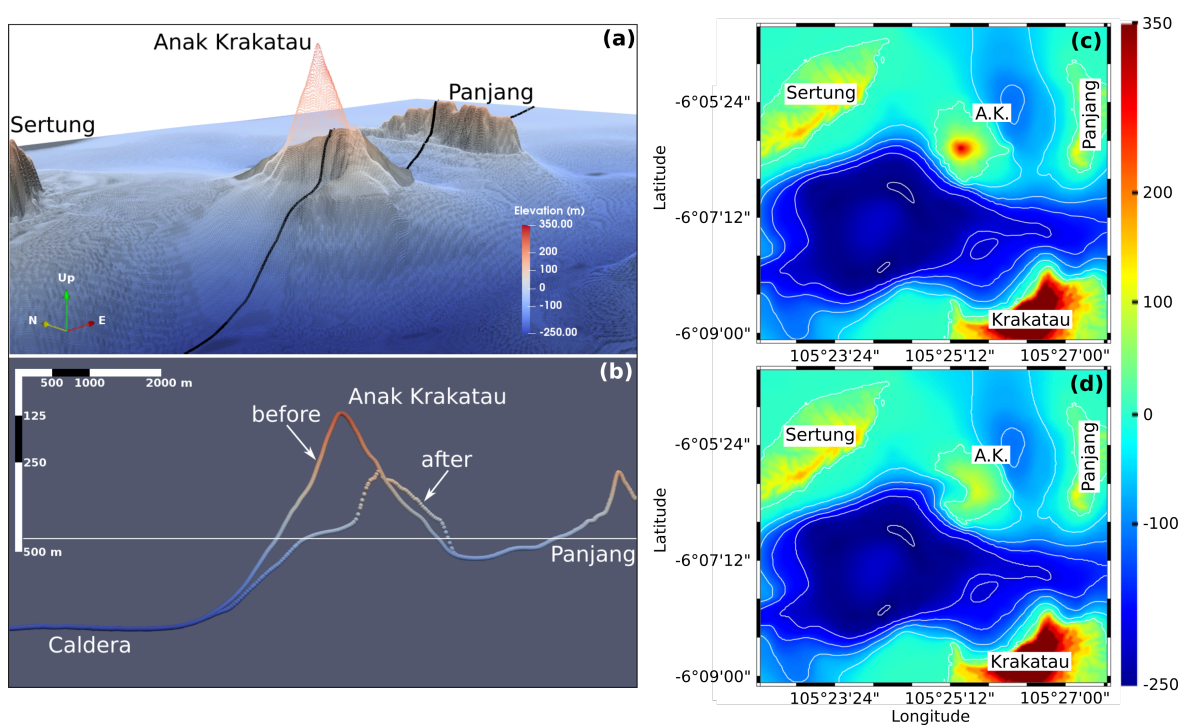

Fig. 7 a Pre and post-collapse topo-bathymetry of Anak Krakatau volcano (dotted grid in transparency illustrating the pre-collapse volcanic edifice); $\mathbf{b}$ Cross-section of the precollapse (solid line) and post-collapse (dotted line) topo-bathymetry following the black line in a. The water surface at rest is represented by the horizontal white line. There is a $\times 5$ vertical exaggeration. The scale in $\mathbf{a}$ and $\mathbf{b}$ is the same and only the view angle changes. Right panels show $\mathbf{c}$ pre and $\mathbf{d}$ post-collapse topo-bathymetry of Anak Krakatau volcano. Bathymetric contours range from 0 to $-250 \mathrm{~m}$ every $50 \mathrm{~m}$. 

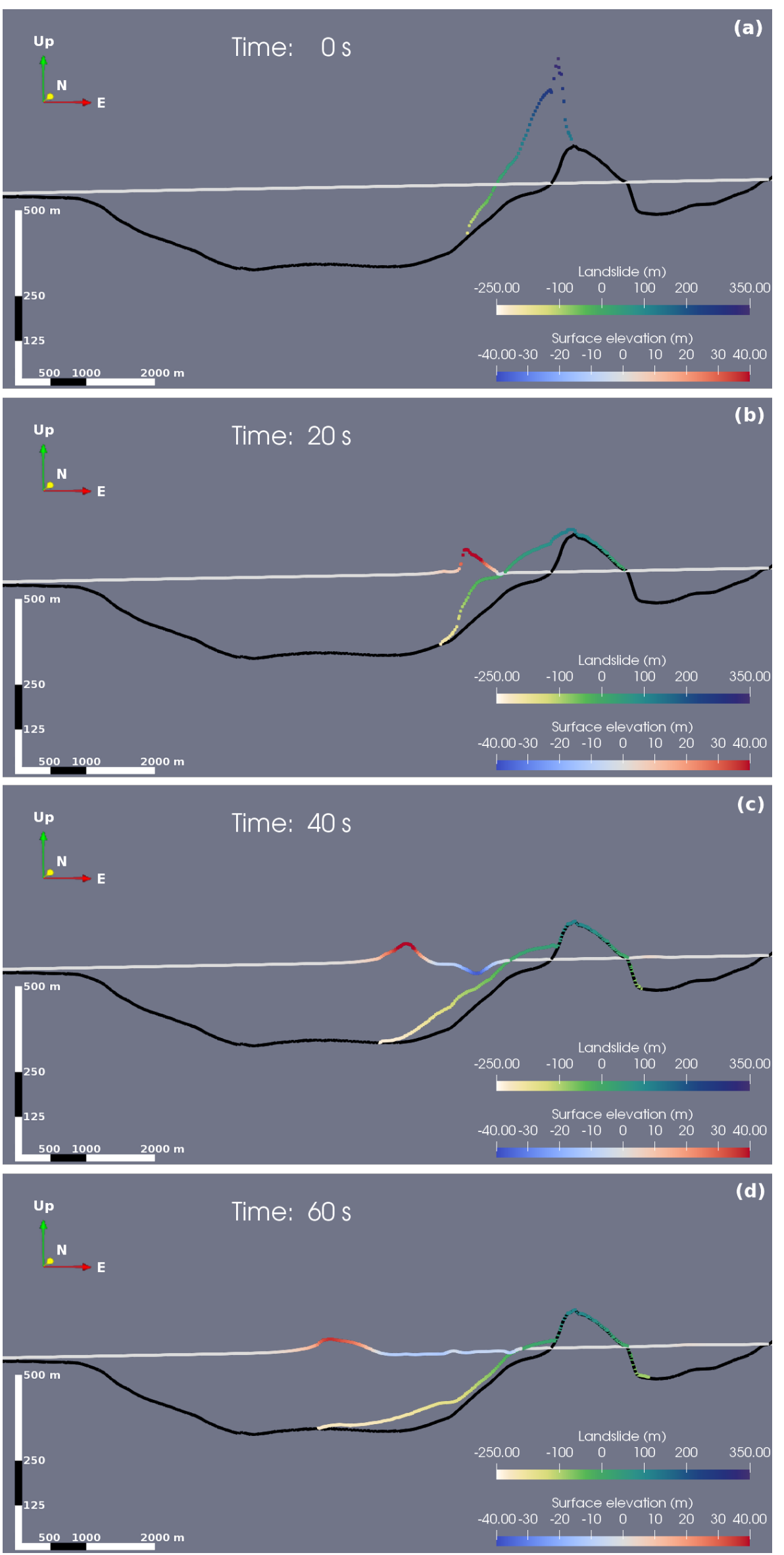

Fig. 8 Snapshots along a W-E cross-section of the simulated water wave (blue to red scale) and landslide (white to dark blue scale) at $\mathbf{a} t=0 \mathrm{~s}, \mathbf{b} \mathrm{t}=20 \mathrm{~s}, \mathbf{c} \mathrm{t}=40 \mathrm{~s}$ and $\mathbf{d} \mathrm{t}=60 \mathrm{~s}$. The post-collapse topo-bathymetry is represented in black solid line. There is a $\times 5$ vertical exaggeration. 


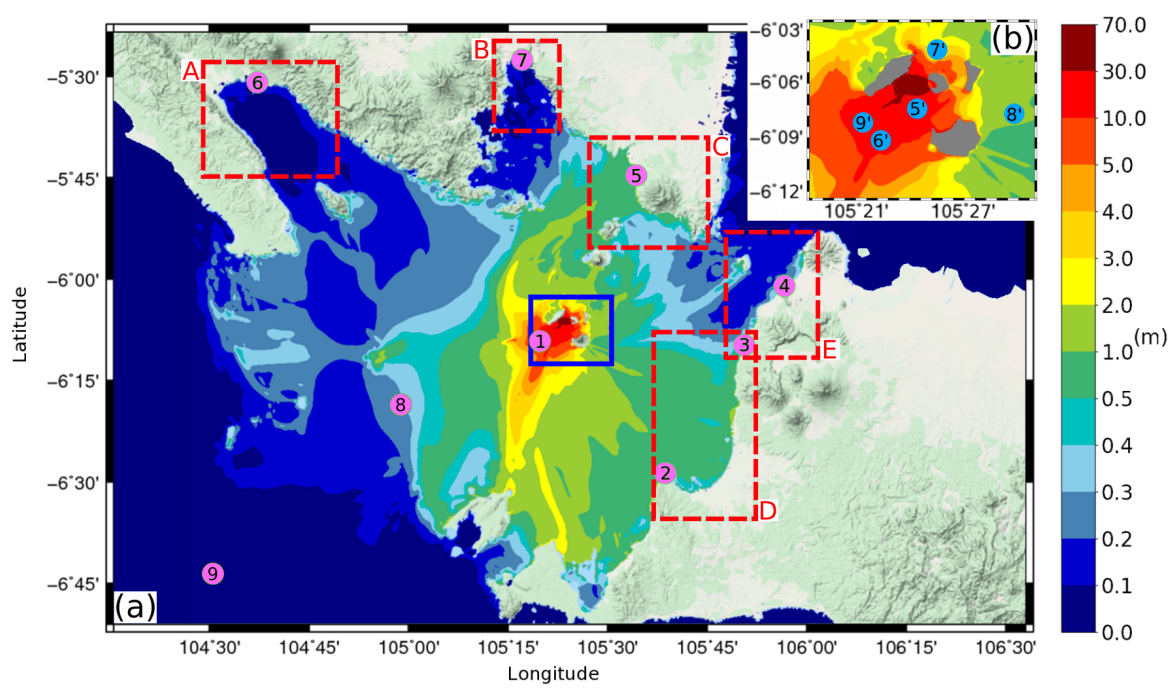

Fig. 9 a Maximum surface elevations computed in Sunda Strait after the collapse of Anak Krakatau volcano. Pink discs with numbers represent the synthetic gauges locations: 10 $\mathrm{km}$ away from the volcano (1), at Tanjung Lesung (2), Marina Jambu (3), Ciwandan (4), Kalianda (5), Kota Agung (6), Panjang (7) and the two gauges (8 and 9) used for the comparison between the shallow water and the Boussinesq models. Child grids described in Section 4.3 are represented by the dashed red rectangles. b Close-up of the results around the volcano, corresponding to the blue box in a. Blue discs with numbers represent the synthetic gauges locations used by Grilli et al. (2019). 

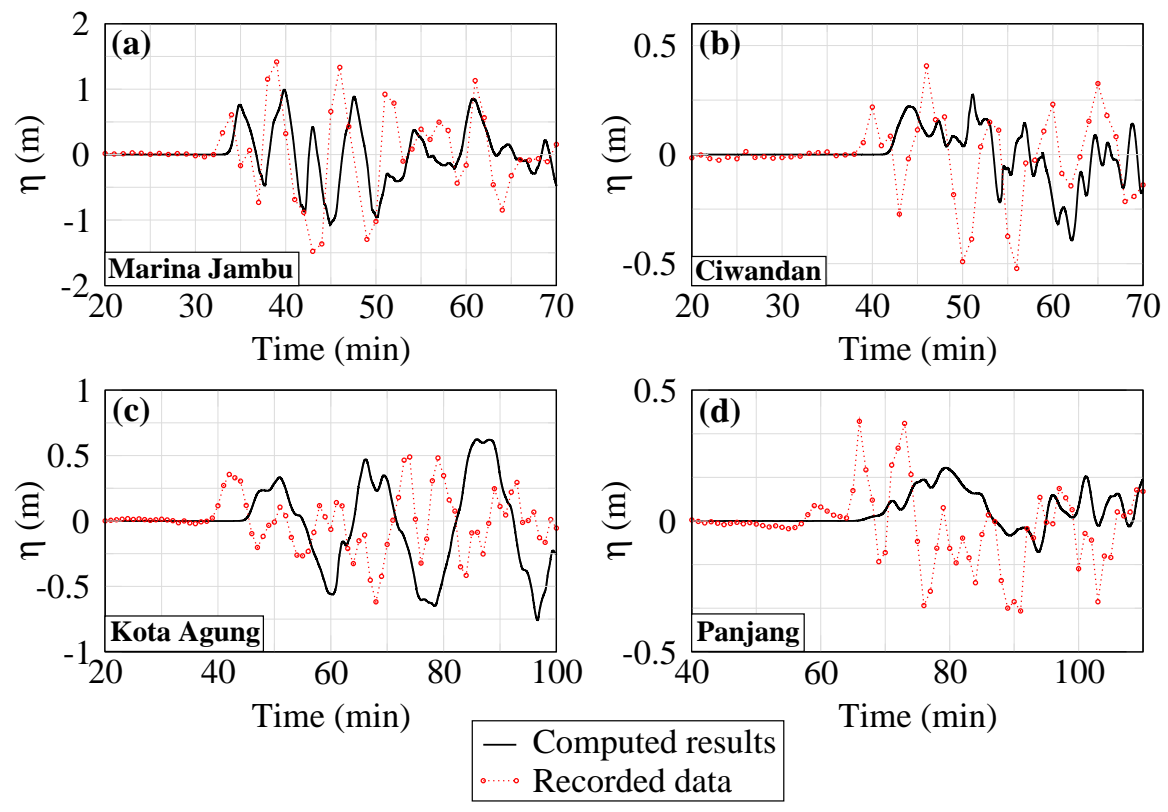

Fig. 10 Comparison between recorded data (in red) and simulated water surface elevations (in black) at a Marina Jambu, b Ciwandan, c Kota Agung and d Panjang (Gauges 3, 4, 6 and 7 , respectively, see Figure 9 . 

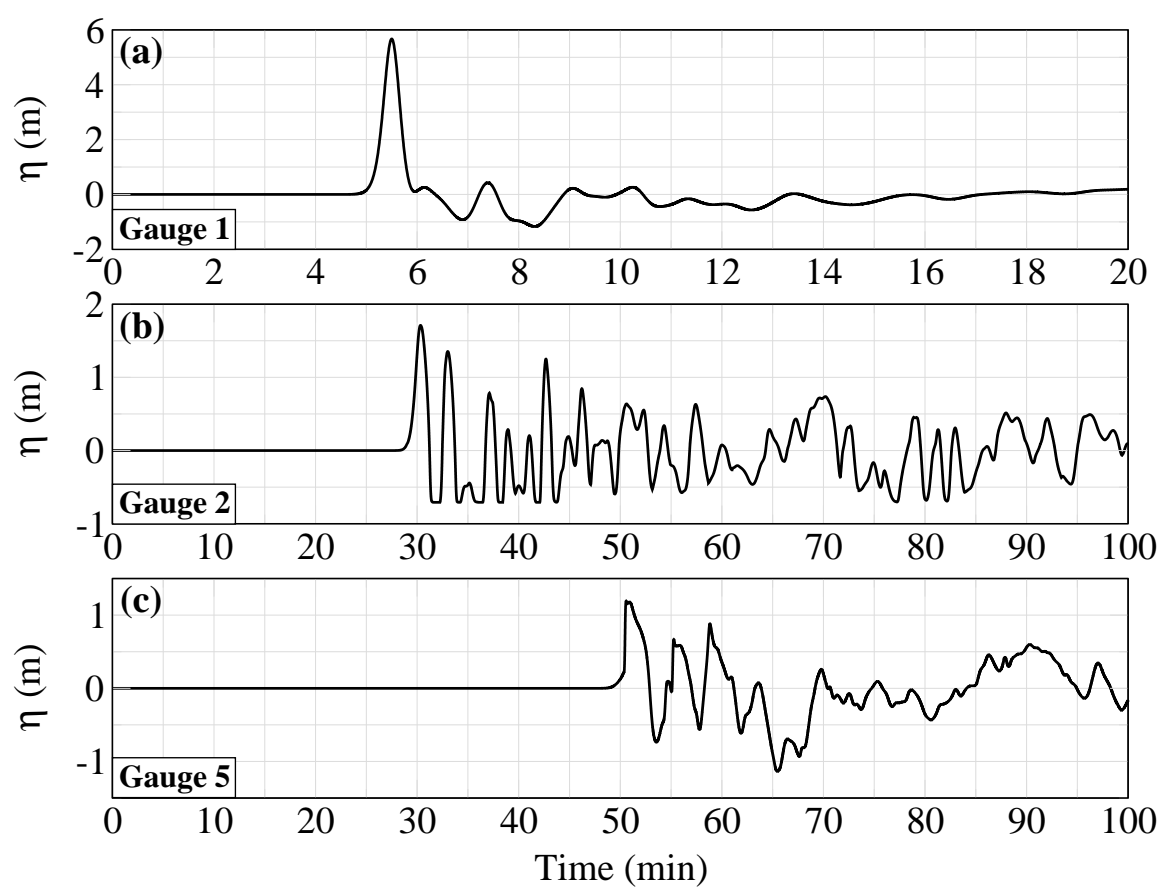

Fig. 11 Computed surface elevations $(\mathrm{m})$ a near the Anak Krakatau volcano, b at Tanjung Lesung and c at Kalianda (Gauges 1, 2 and 5, respectively, see Figure 9. 

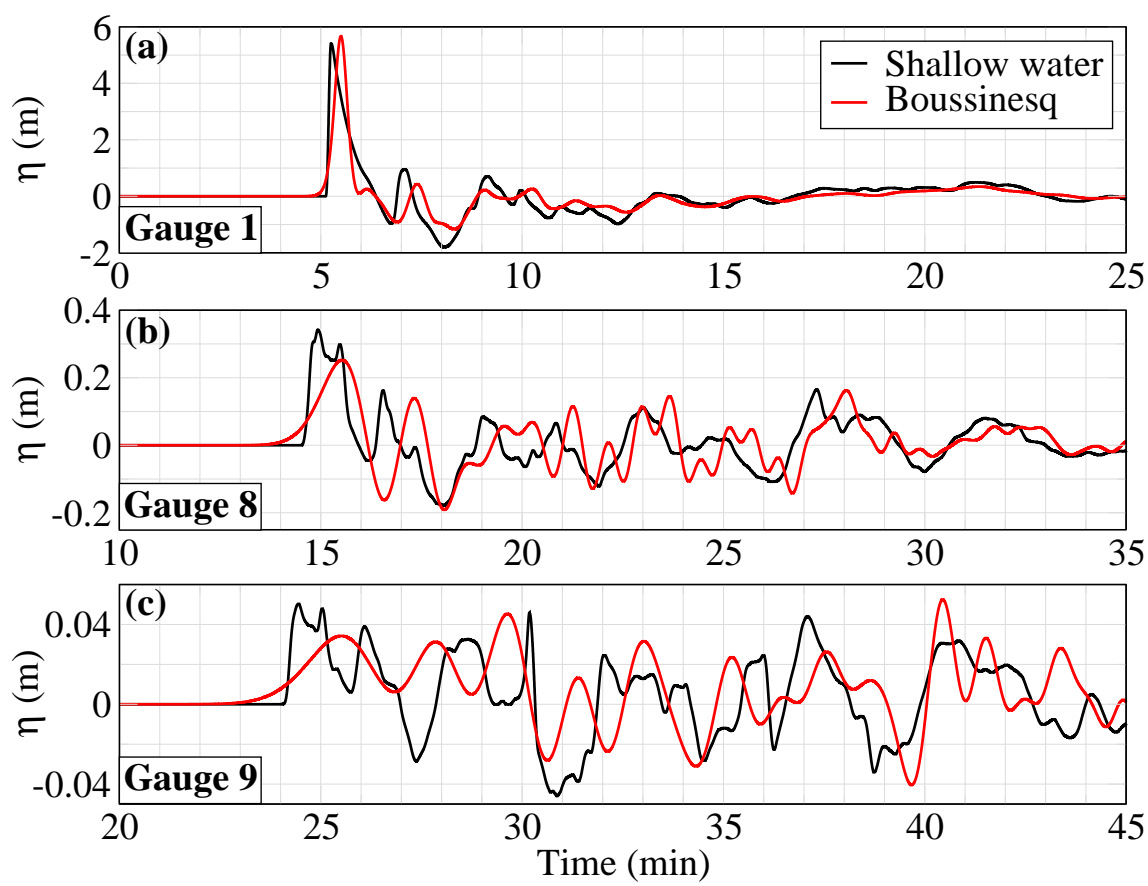

Fig. 12 Comparison of time series calculated by the shallow water (in black) and the Boussinesq (in red) models at Gauges a 1, b 8 and $\mathbf{c} 9$ (Figure 9). The water depths of these gauges are: a $100 \mathrm{~m}, \mathbf{b} 1140 \mathrm{~m}$ and $\mathbf{c} 1960 \mathrm{~m}$.

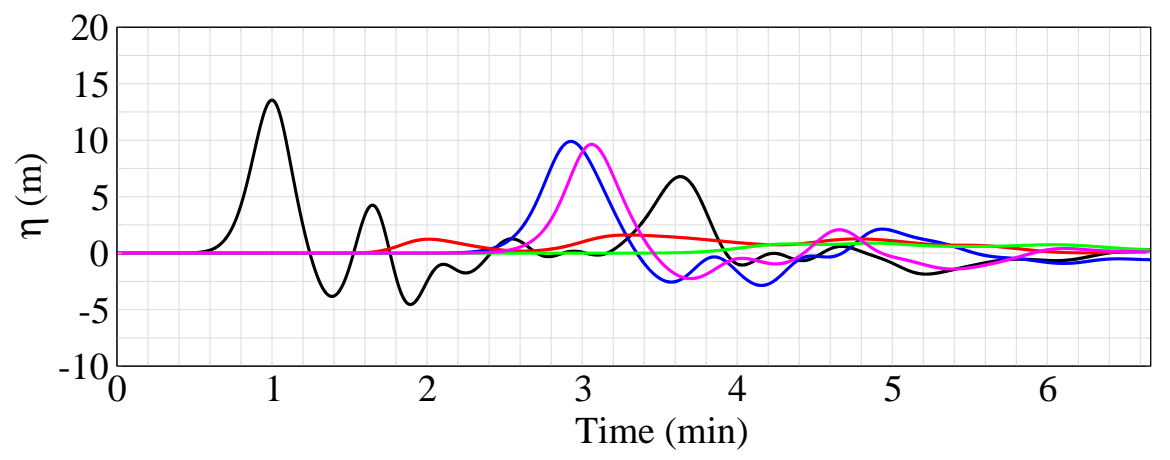

Fig. 13 Time series of surface elevation calculated in the near-field by our model (150 million $\mathrm{m}^{3}$ and the code AVALANCHE) at the Gauges 5' (black), 6' (blue), 7' (red), 8' (green) and 9' (magenta) used by Grilli et al. (2019) and presented in Figure 9p. Results are very similar to those presented in Figure 5e of Grilli et al. (2019). 